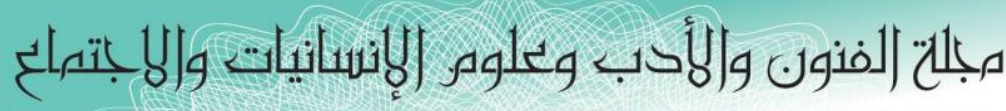

Journal of Arts, Literature, Humanities and Social Sciences

ISSN online: 2414 - 3383

ISSN print: 2616 - 3810
حزيران - يونيو 2019

العدد (39)

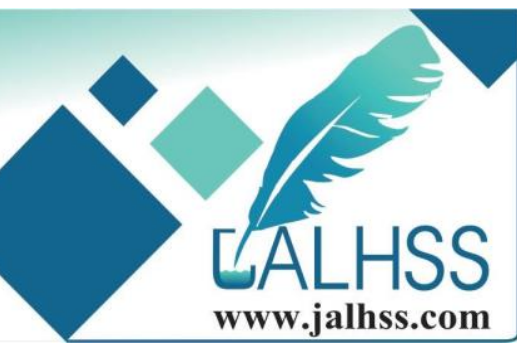

\title{
دور وسائل الإعلام في تشكيل الرأي العام
}

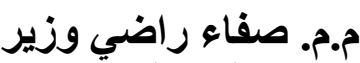 \\ مديرية تربية ذي قار منار \\ العراق
}

\section{The Role of the Media in Shaping of Public Opinion}

\begin{abstract}
The subject of the media has attracted the attention of many intellectuals, academics and researchers, because it has a role in raising the public's attention to the issues and problems. So this study was launched to learn about the role of the media in shaping public opinion. The aim of this study was to reveal the extent to which the media contributed to shaping public opinion by identifying the content of these media outlets, and also to monitor the spread of the media and to study the impact on the awareness of viewers and listeners.

In order to achieve the objectives of the research, the researcher used the descriptive approach, which aims to monitor a specific phenomenon or topic in order to understand its content. The researcher adopted the questionnaire and applied it to a sample of the community of Nasiriyah, Their views and attitudes from the media, and their relationship to forming their views on various issues. The results of the study showed that the media have a great role to form their opinions on the various issues presented by these means. They also showed that the respondents rely on the media to build their culture. They also see that the media meet all their concerns and provide them with everything they need of information.
\end{abstract}




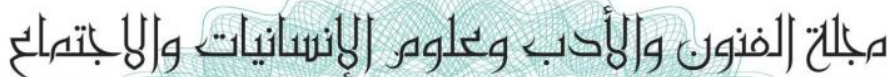

\section{العدد (39) ريران - يونيو 2019}

المقدمة

تطورت وسائل الإعلام وتعددت في السنوات الأخيرة تطورا هائلا بفضل التقدم العلمي، والثورة التكنولوجية التي التيات

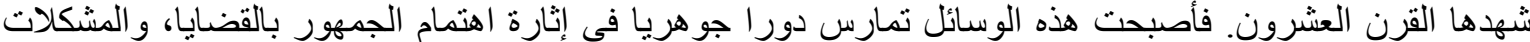

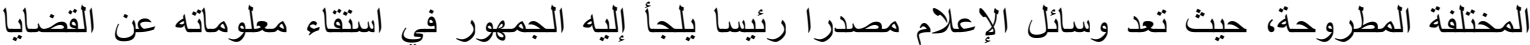

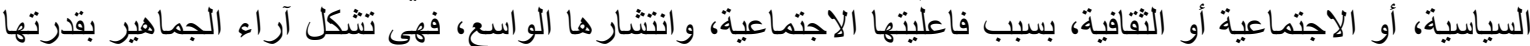

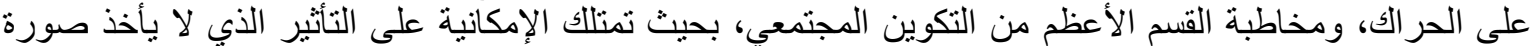

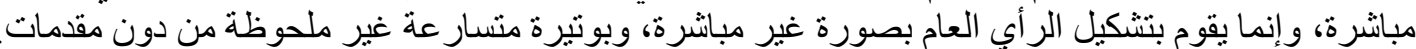

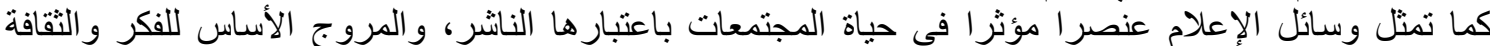

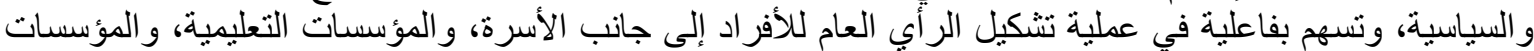

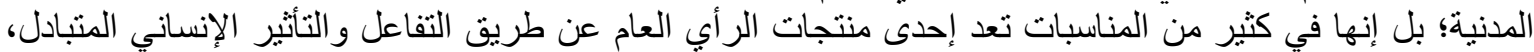

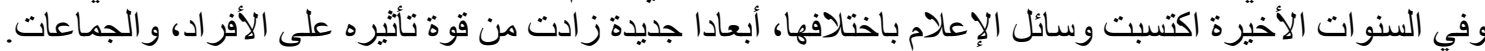

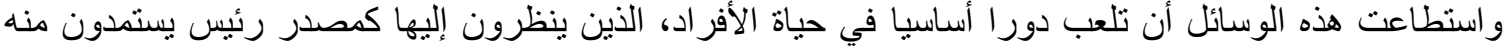

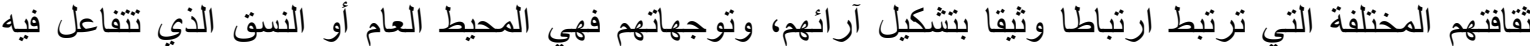
المجتمعات، وتستمد منه مضمونها الاجتماعي، و السياسي، و والثقافي.

\section{المبحث الأول الإطز \\ الإطار النظري}

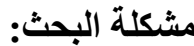

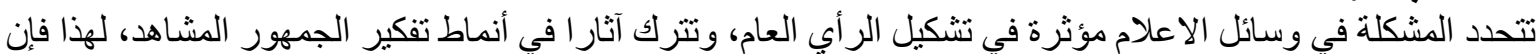

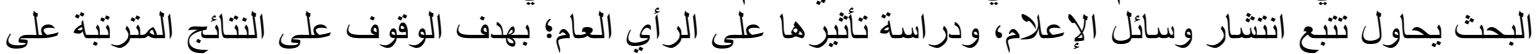

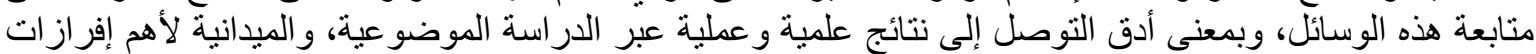

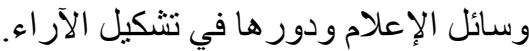

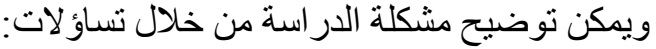

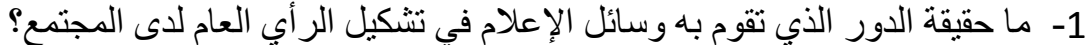

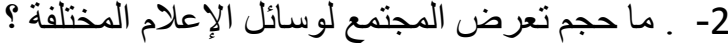
3- ما هي العو امل التي تؤثر في زيادة مشاهدة وسائل الإعلائل الإعلام من قبل المشاهدين؟

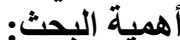
تنطلق أهمية هذا البحث من خلال الدور المتنامي تأثثير ا وفاعلية لوسائل الإعلام في تشكيل الآراء، والتصور اتثرات في

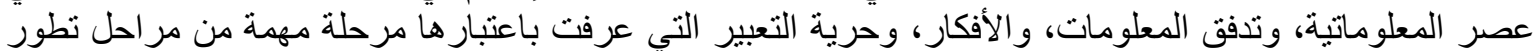

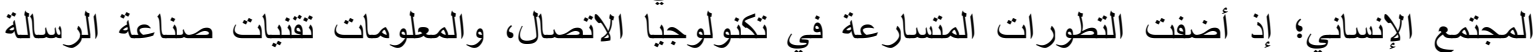

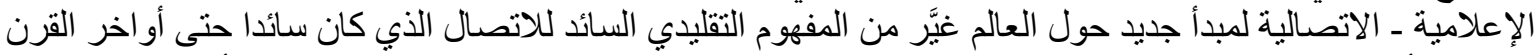

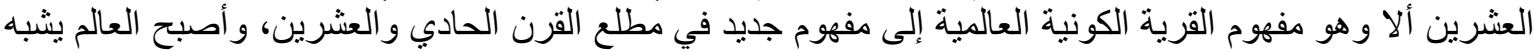
بكونه عمارة في شار ع ضيق يتنافس عليها الجميع للحصول الكية على مساحة للعيش فيها.

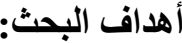

1- التعرف على دور وسائل الإعلام في عملية بلورة الر أي العام، وتشكيله حول قضايا الفرد، و المجتمع المختلفة.

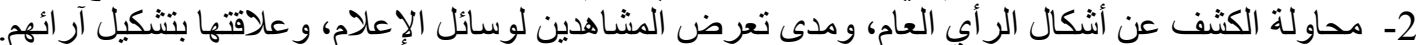

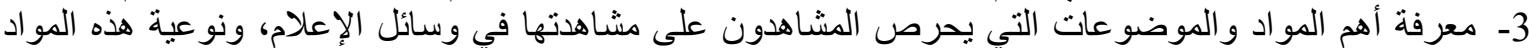
و الموضو عات التي تشكل آر ائهر.

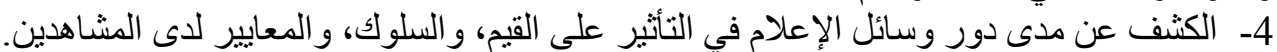

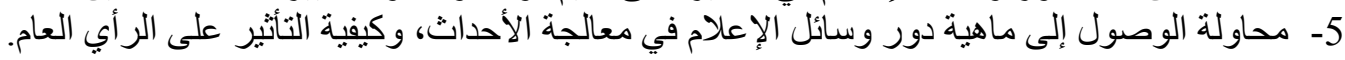




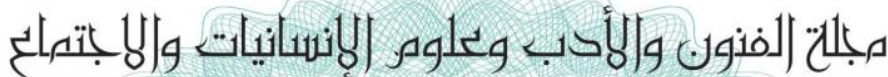

\section{العدد (39) حزيران - يونيو 2019}

6. لفت الانتباه إلى ضرورة الاهتمام بالدر اسات المتخصصة في الإعلام و الدور الذي تقوم به وسائله في تشكيل الر أي

منهج البحث ونوعه:

ينقسم البحث على جانب نظري و وعلي، لذا اعتمد الباحث على: المنهج الوصفي، الذي يهدف إلى رصد ظاهرة أو

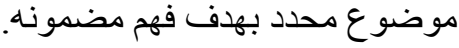

حدود البحث :

أـ الحدود الموضو عية: در اسة دور وسائل الإعلام في تشكيل الر أي العام، وصناعته.

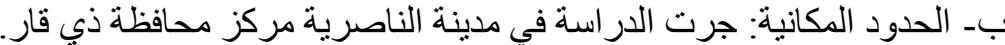

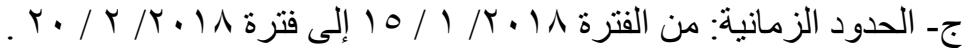

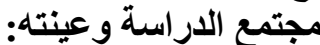

يتمثل مجتمع البحث في هذه الدر اسة الميدانية في جمهور وسائل الإعلام من خلائل عينة من المشاهدين، و المتابعين

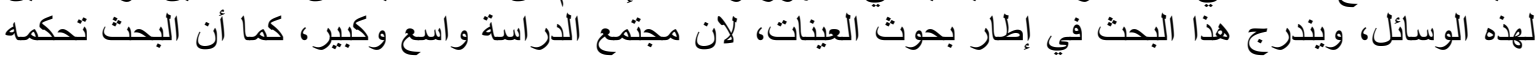

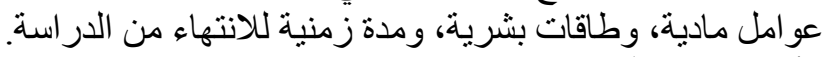

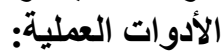
اعتمد الباحث في هذه الدراسة على الإدى (أداة استمارة الاستبيان) التي وجهت إلى جمهور عام من مدينة الناصرية، وهي

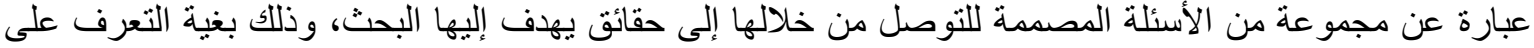
دور وسائل الإعلام في تشكيل الر أبي العام. تحديا المصطلحات: 1- الدور: يعرفه الباحث بأنه: التبعات والمسؤوليات و المهام الملقاة على عاتق وسائل الإعلام في تحقيق وظيفة الحد من

الجريمة البيئية.

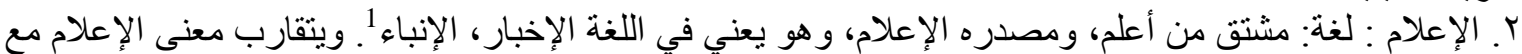

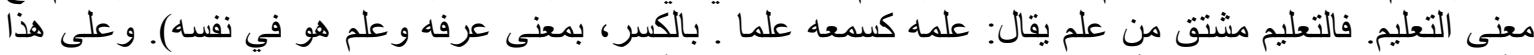

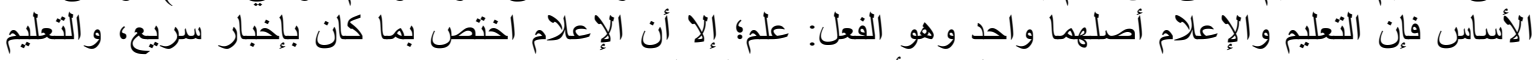

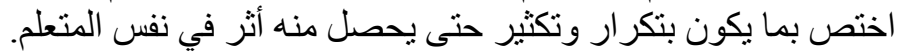

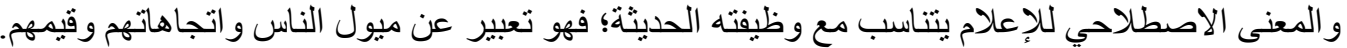

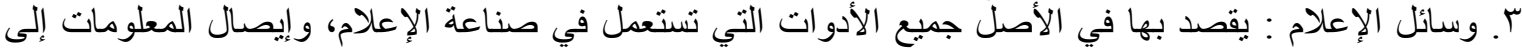

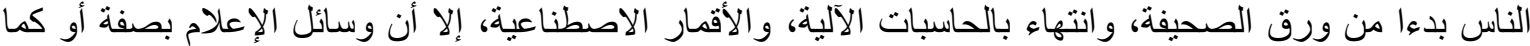

تسمى (وسائل الاتصال الجماهيري) تنقسم بصفة عامة على وسائل مقرو عةد، سمعية ووسائل بصرية، وسمعية.

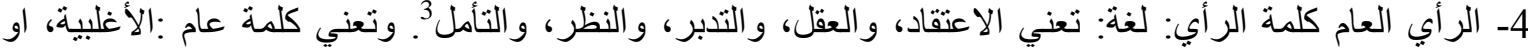
الثامل، و عكسه الخاص. وفي المعنى الاصطلاحي: يشير إلى التعبير الإر ادي عن وجهات نظر الجماهير نتيجة التقاء كلمتها، وتكامل مفاهيمها

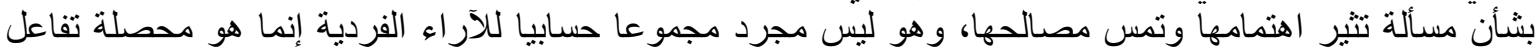

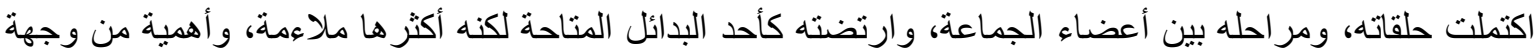

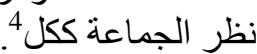
الار اسات السابقة: الظمة

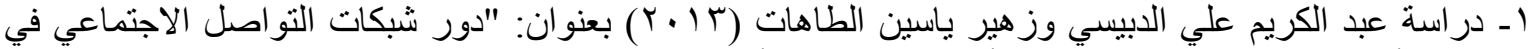
تشكيل الر أي العام لدى طلبة الجامعات الأردنية"، تتلخص أهداف الدراسة في معرفة معدلات استخدام طلبة الجامعات

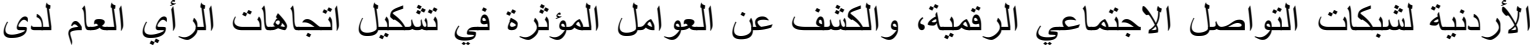

'زواوي الحاج سعيد، اتجاهات الجمهور نحو البرامج الإخبارية لقناة الجزيرة، مذكرة ماجستير في علم الاجتماع، جامعة

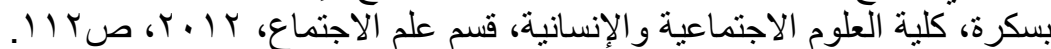

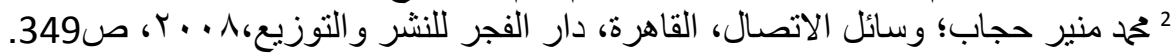

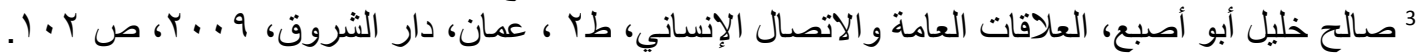

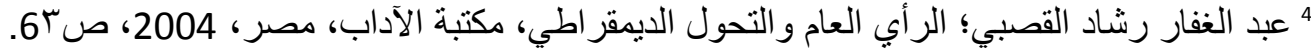




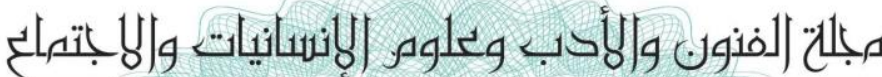

\section{العدد (39) ريران - يونيو 2019}

الطلبة، ومستوى منافسة شبكات التواصل الاجتماعي لوسائل الإعلام التقليدية، باعتمادها مصادر للأخبار و المعلومات.

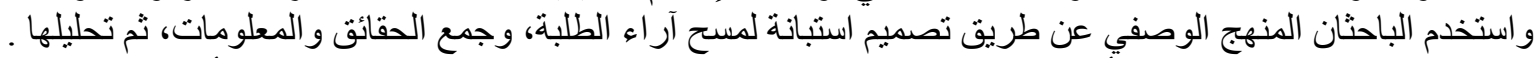

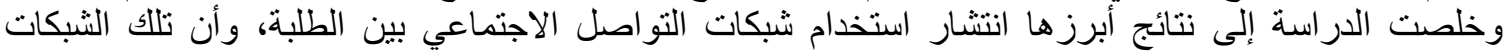

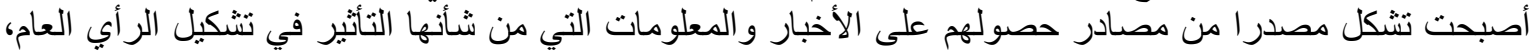

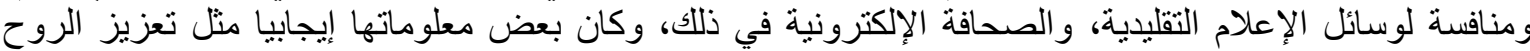

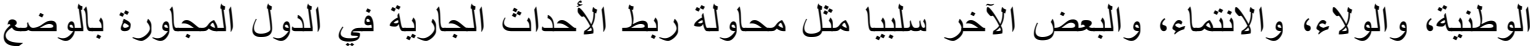

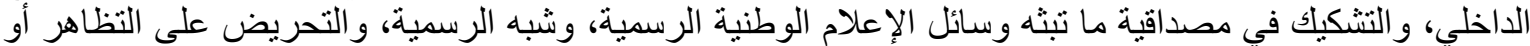

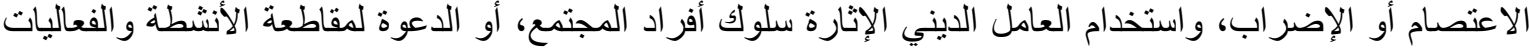

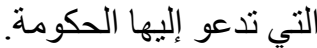

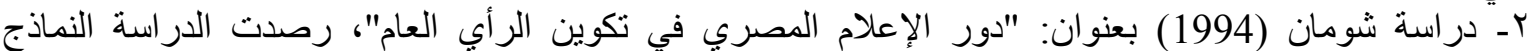

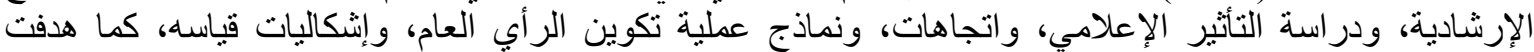

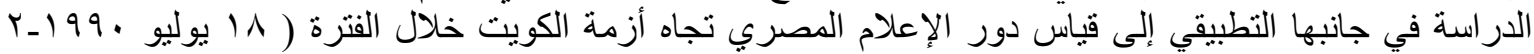

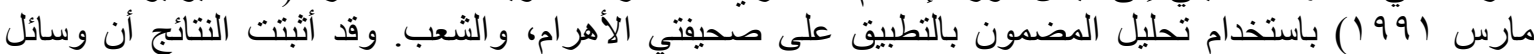

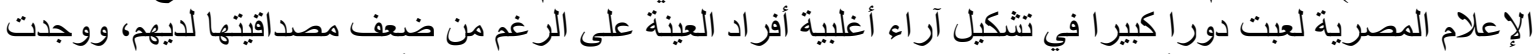

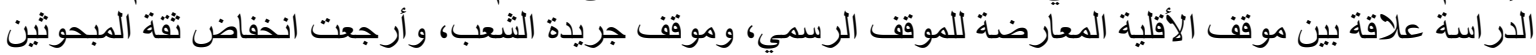

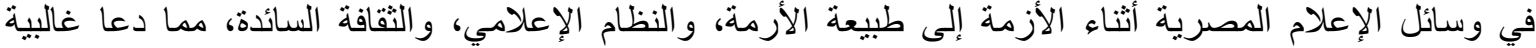
المبحوثين إلى تعويض أزمة المصداقية بزيادة الاعتماد على الإذاعات الأجنبية الموجهة باللغية العربية، وشبكة الاتصال

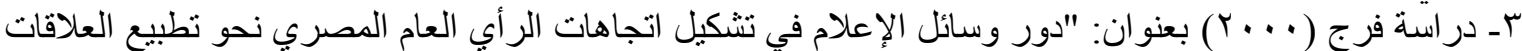

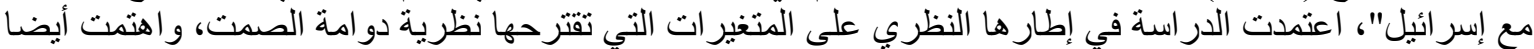

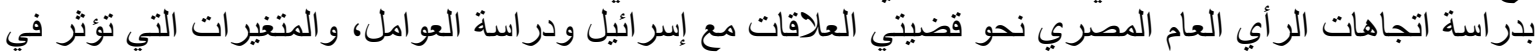

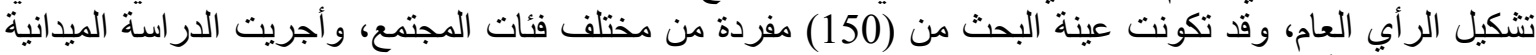

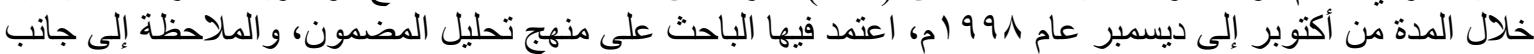

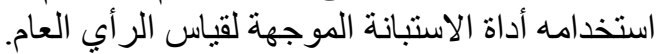

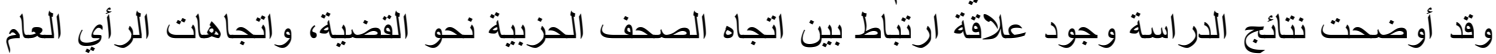

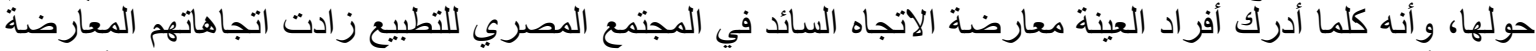

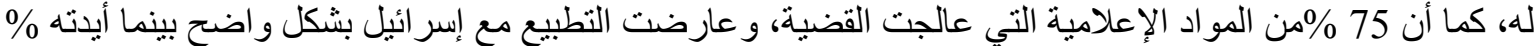

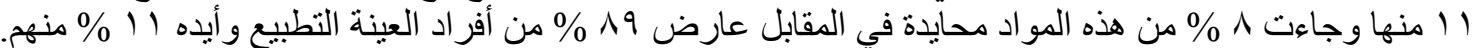

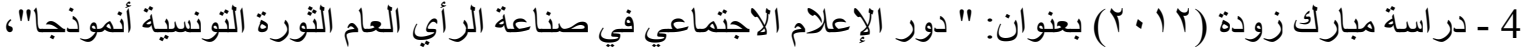

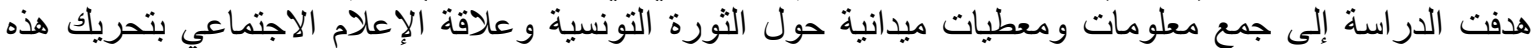

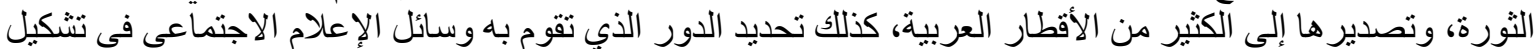

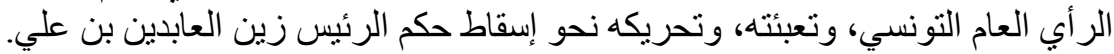

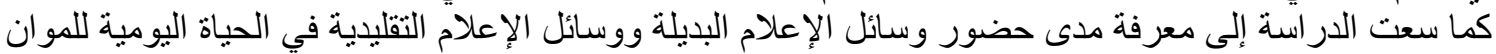

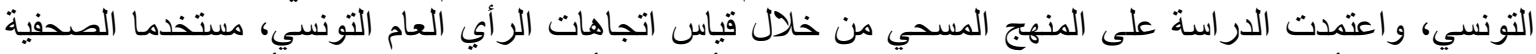

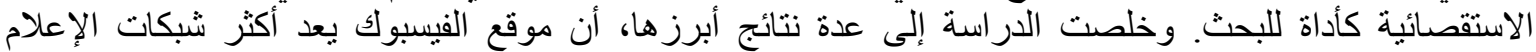

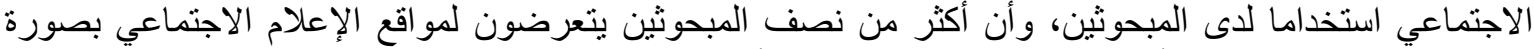

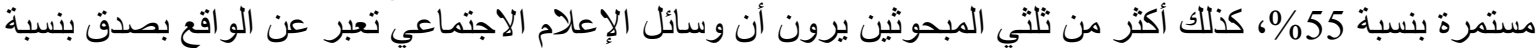

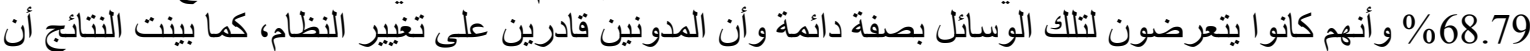

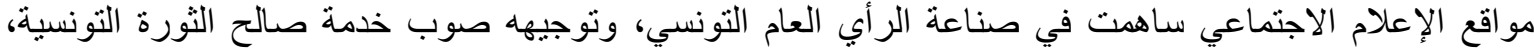
ولكنها لم تصنع الثورة و إنما ساهدت بشكل كبير فعال ومباثر في إنجاحها. 


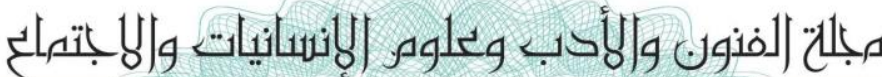

\section{العدد (39) ريران - يونيو 2019}

\author{
وسائل الإعلام ودورها في تشّكيل الرأي العام
}

أولا- وسائل الإعلام : مفهومها وتعريفها وأنواعهاو وظائفها

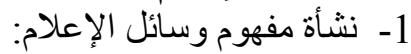

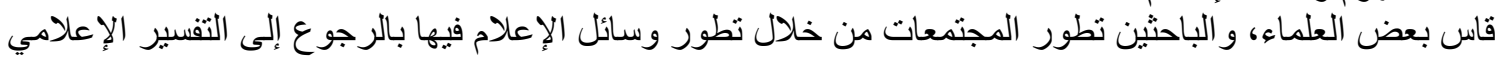

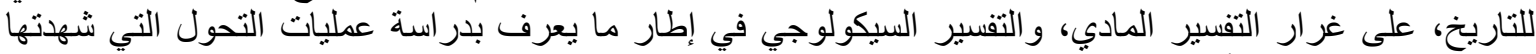

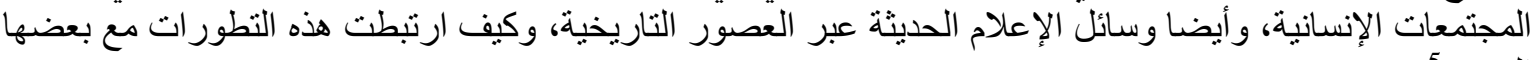
البعض د.

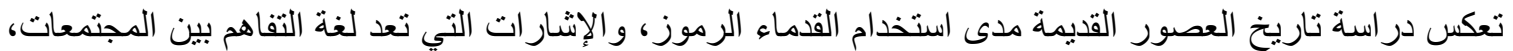

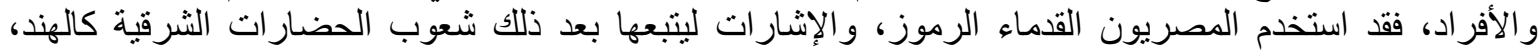

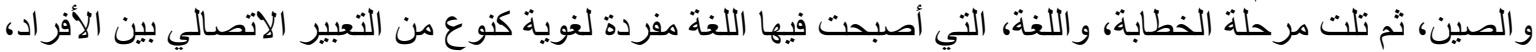

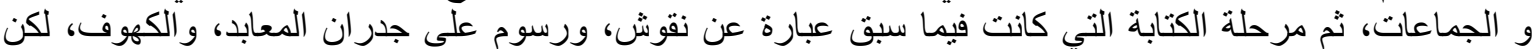

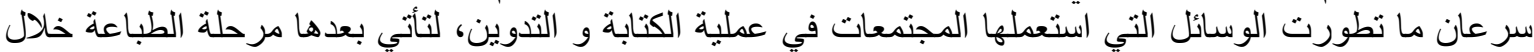

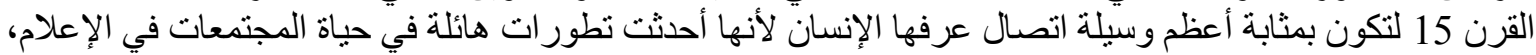

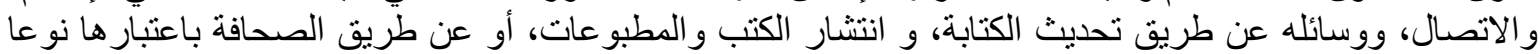
من الصحافة المكتوبة،

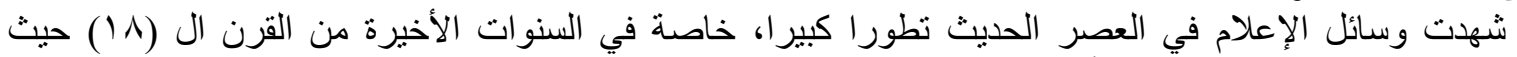

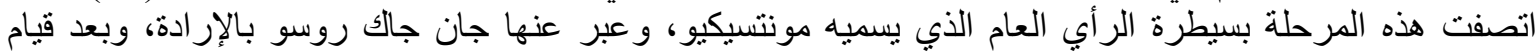

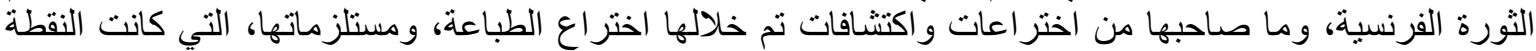
الفاصلة بين العصور القديمة، و العصر الحئية العديث.

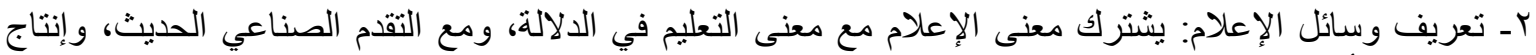

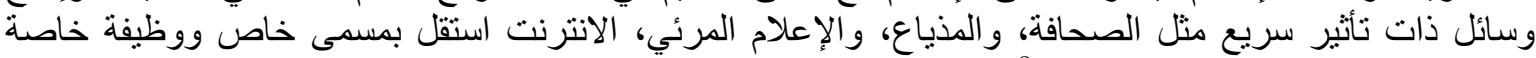

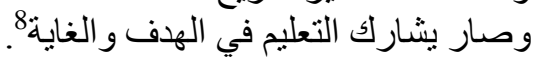

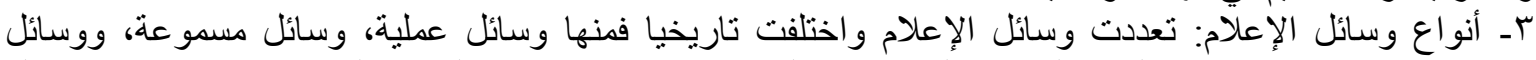

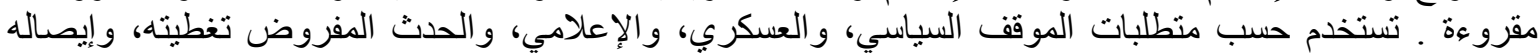

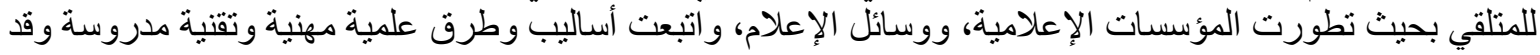

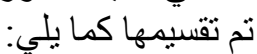

• الوسائل التقليدية: : هناك العديد من وسائل الإعلام التقليدية منها:

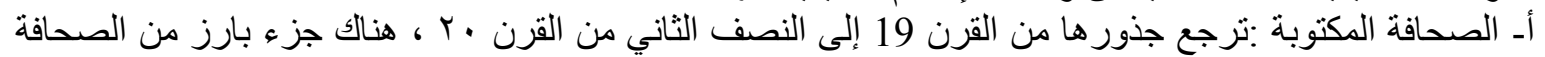

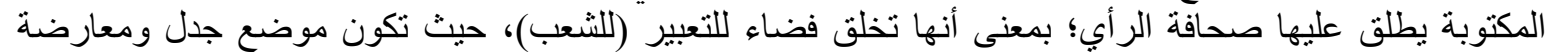

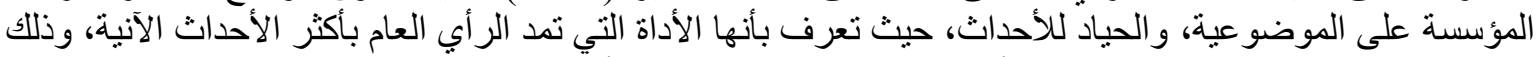

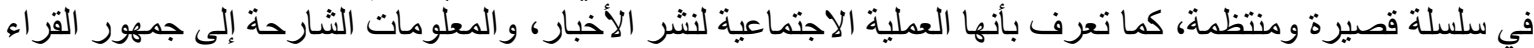

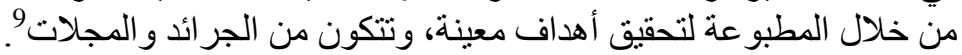

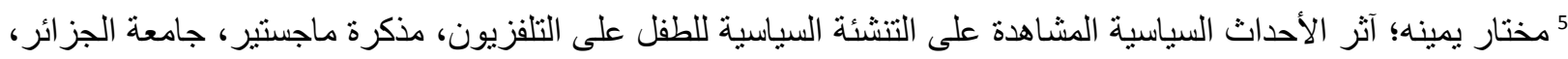

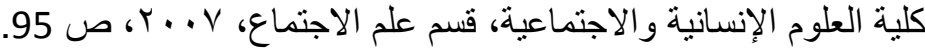

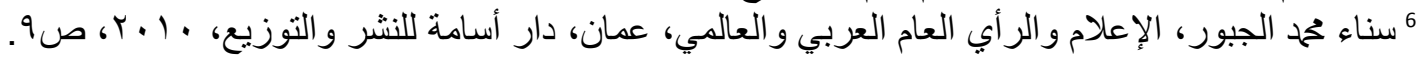

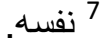

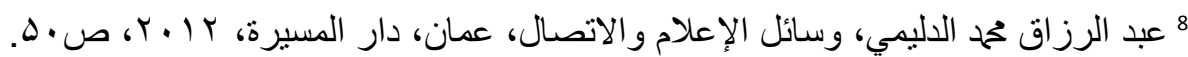

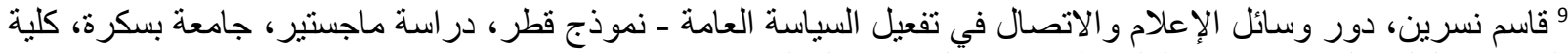

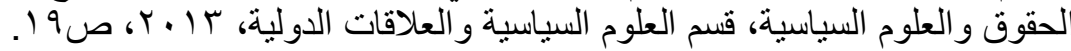




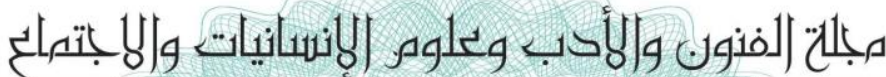

\section{العدد (39) ريران - يونيو 2019}

تـ التلفزيون : يعرف التلفزيون لغويا : مكونا من مقطعين: Télé : معناه عن بعد. Vision : معناه الرؤية أي هو

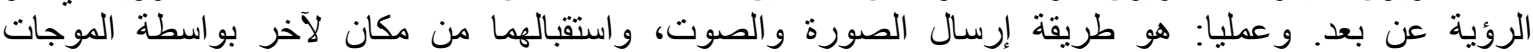

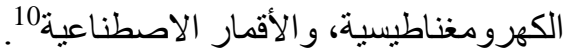
يعرف أنه " وسيلة نقل الصورة والصاعة الصوت في وقت واحد عن طريق الدفع الكهربائي بمعنى بواسطة الموجات

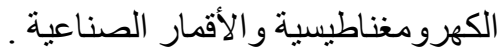
التكون التلفزيون من القنوات الفضائية والمحلية؛ وهي قنوات التئ تبث عبر شبكة من الأقمار الصناعية التي تدور حول

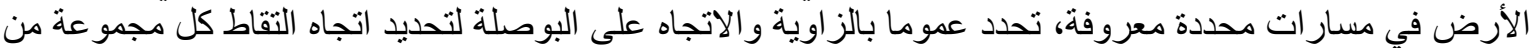

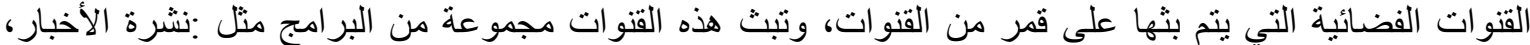

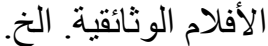
ج- الإذاعة : قد تكون الإذاعة الآن من الوسائل الفعالة في توصيل الرسائل إلى جماهير عريضة، فهي تسنطيع أن

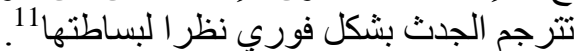

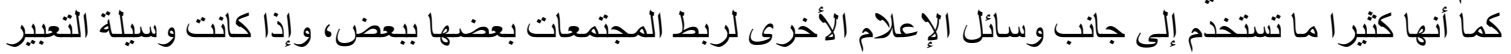

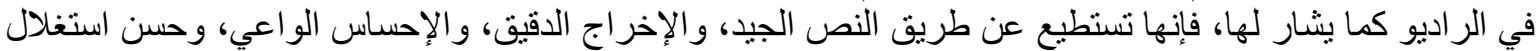

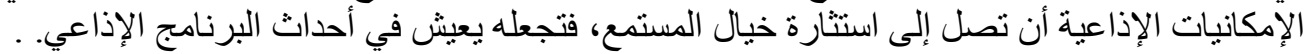

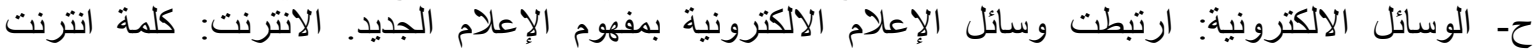
هي اختصار الكلمة الانجليزية (Internet)

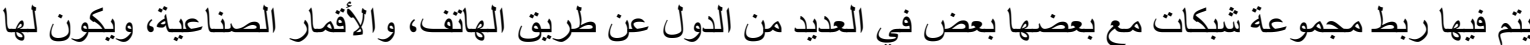

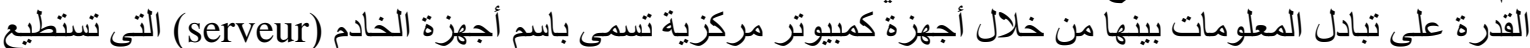

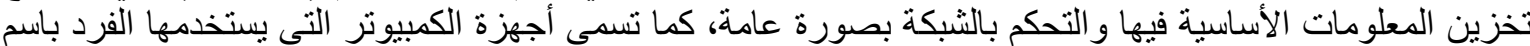

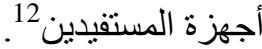

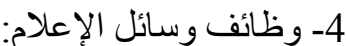

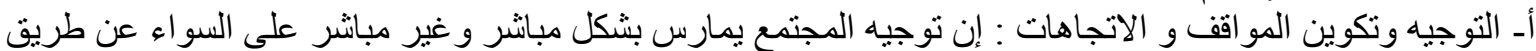

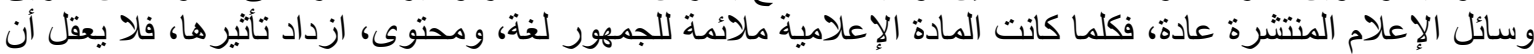

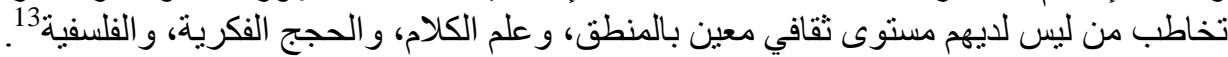

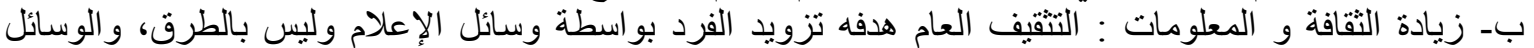

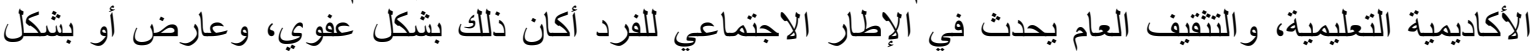

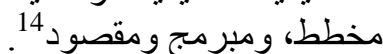

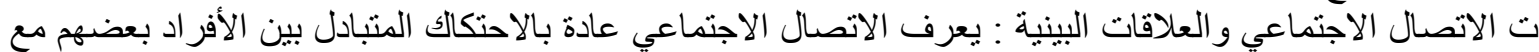

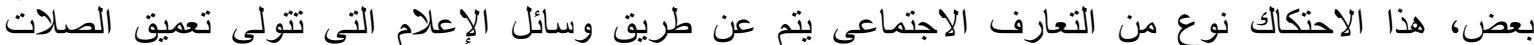

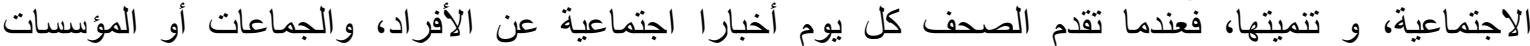

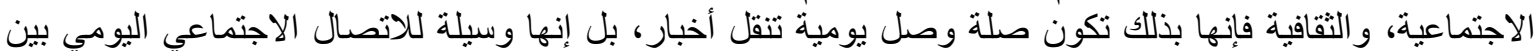
جميع فئات الجماهير.

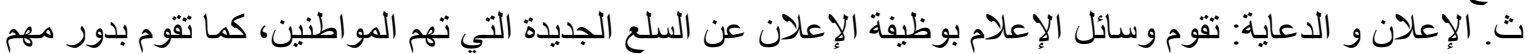

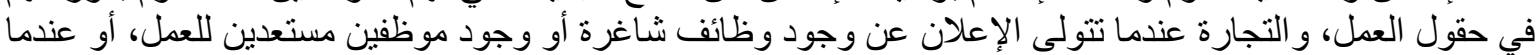

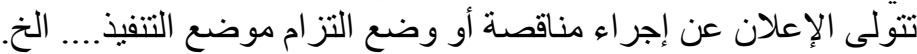

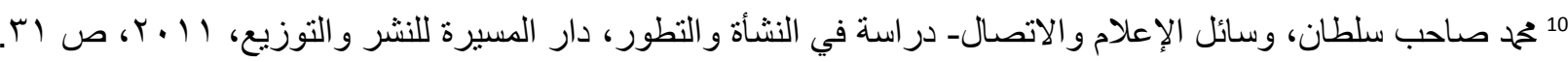

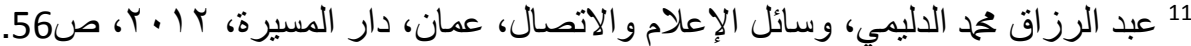

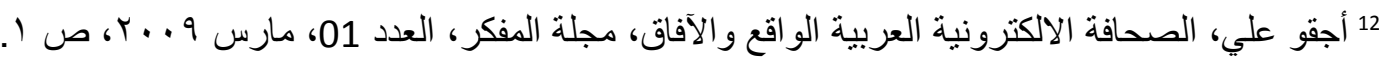

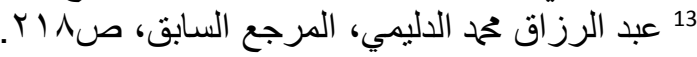
14 بن عودة العربي؛ إسهام وسائل الإعلام في ترقية المجتمع، مذكرة ماجستير، في علوم الإعلام والاتصال، جامعة وهران،

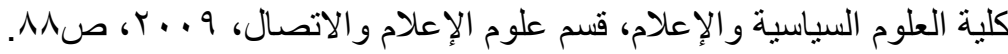




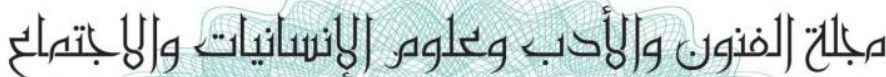

\section{العدد (39) ريران - يونيو 2019}

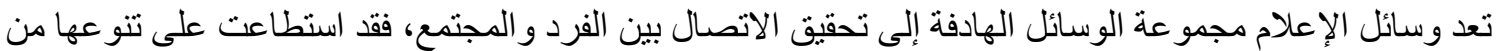

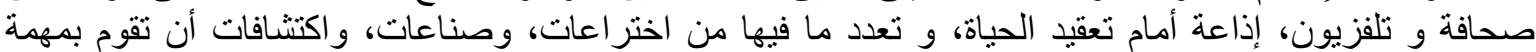

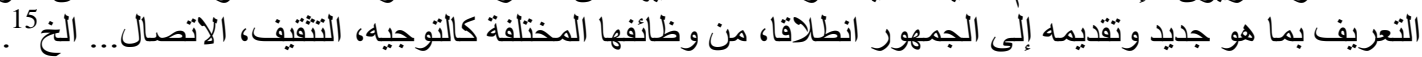

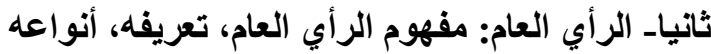

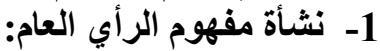
إن الر أي العام قديم قدم البشرية وإن كان كاصطلاح من مصطلحات العصر العابِ العديث الذي تعددت فيه وسائل التعبير

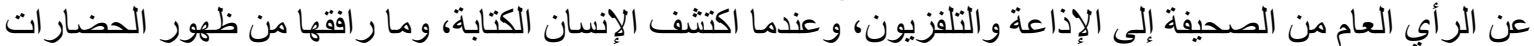

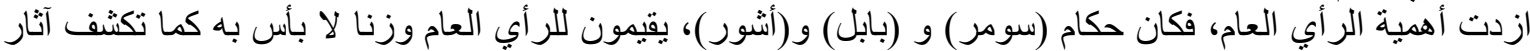

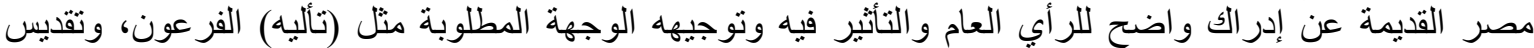

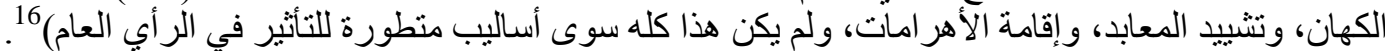

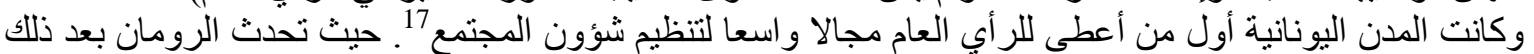

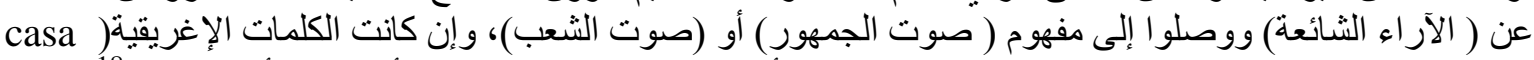

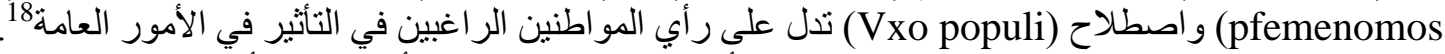

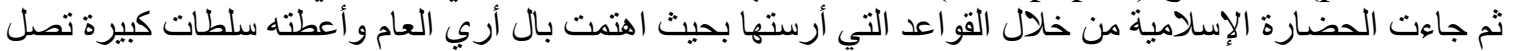

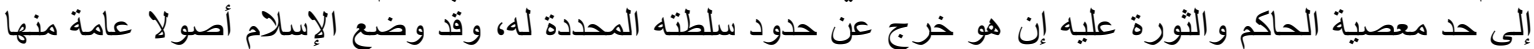

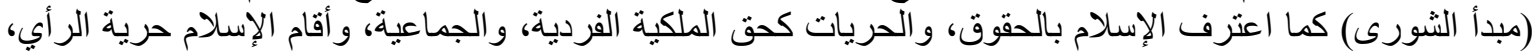

وحرية العقيدة وغير ذللك من الحريات العامة.

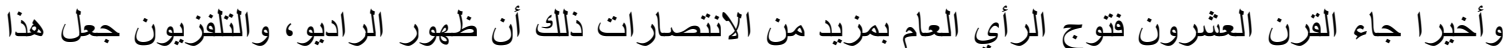

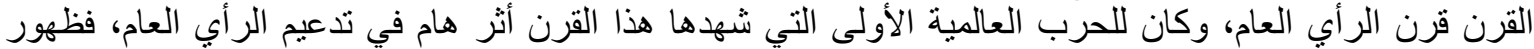

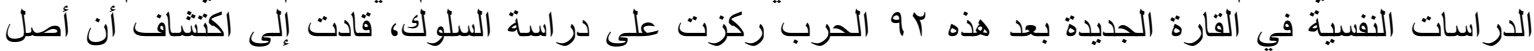

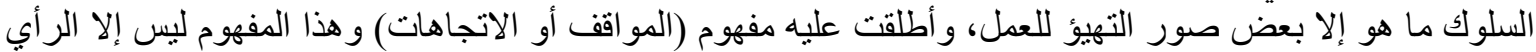

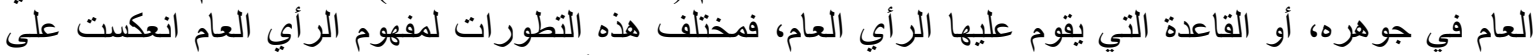

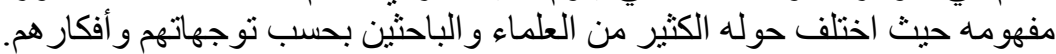

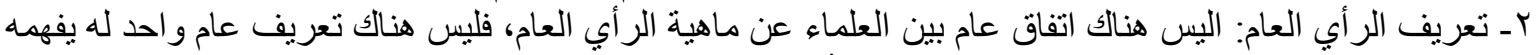

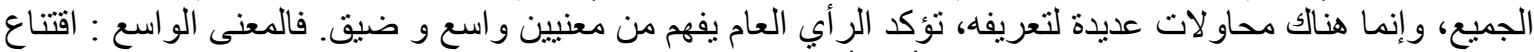

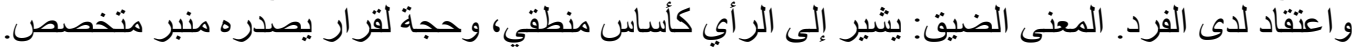

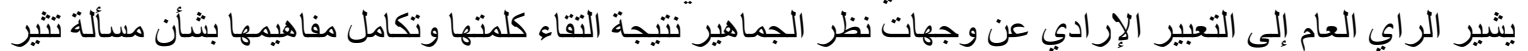

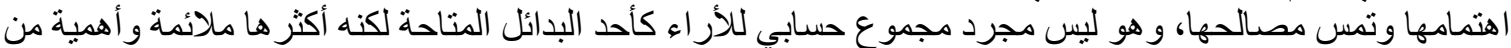

وجهة نظر الجماعة ككل 19.

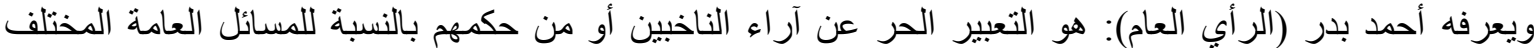

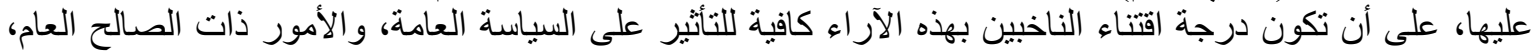

بحيث يكون هذا التعبير ممثنلا لر أي الأغلبية.

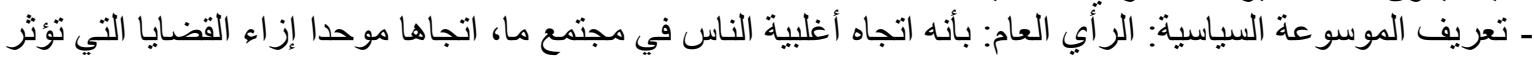

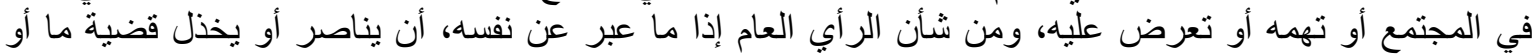

اقتر احا معينا، وكثير ا ما يكون قوة موجهة للسلطات الحأكمة.20.

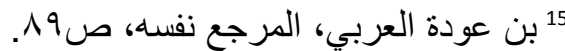

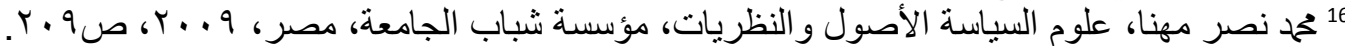

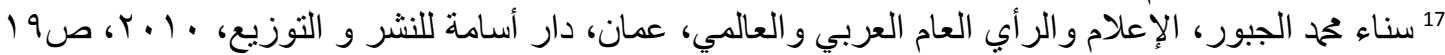

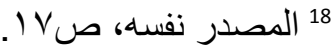

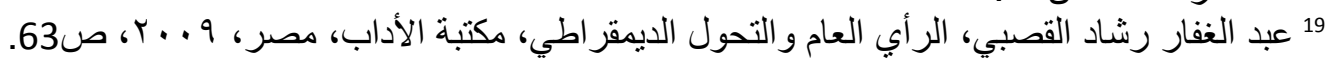

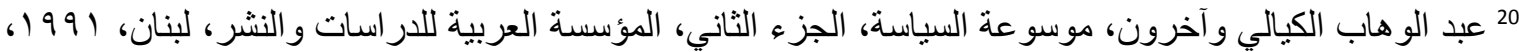

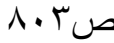




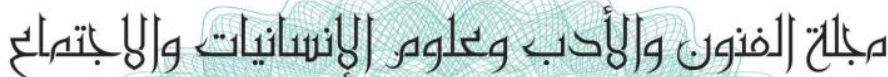

\section{العدد (39) حزيران - يونيو 2019}

ـ فمن التعريفات السابقة فإن طبيعة الر أي العام و خصائصها تتوقف على العديد من العو امل و المتغيرات و من أهمها و

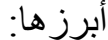

1- وجود قضية أو مسألة : القضية هي موضوع - مع احتمال عدم الاتفاق حوله - وهو اهتمام عام من المجتمع وليس

الفرد فقط

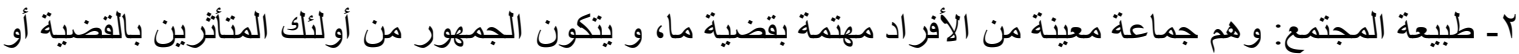

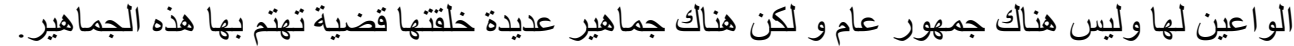

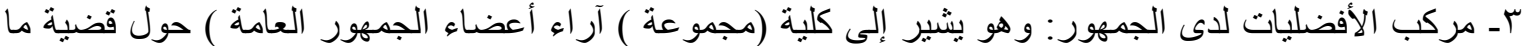

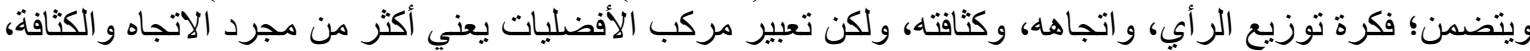

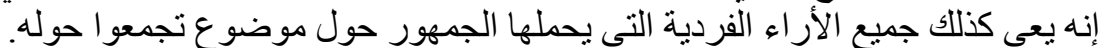

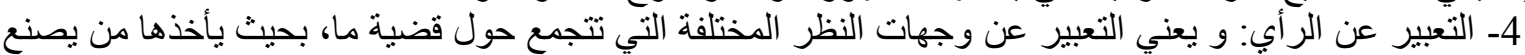
القرار بالحسبان عند التعامل معها وهو ليس شناملا لكل من يعيش في المجتمع كما أنه ليس ثابت بل يتغير بتغير المسائل

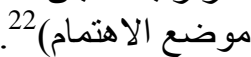

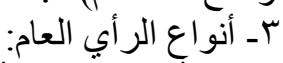

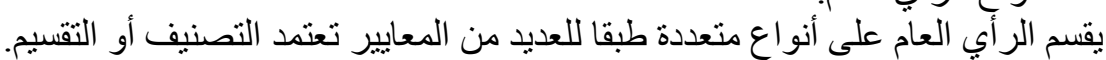

تقسيم الرأي العام حسب طب العبيعته:

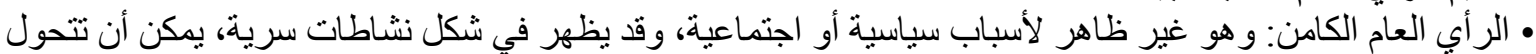

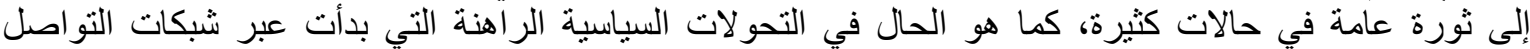

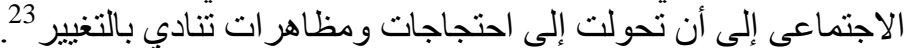

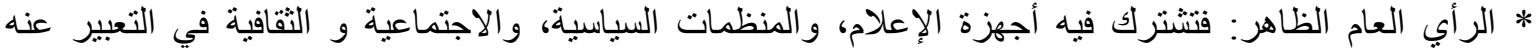

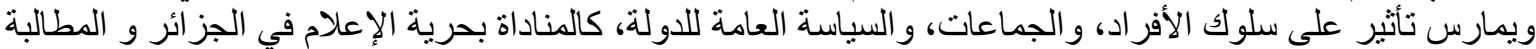

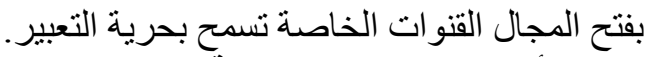

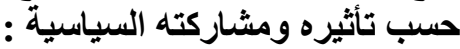

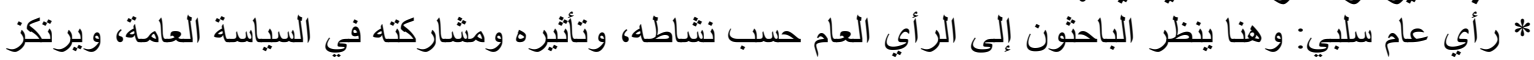

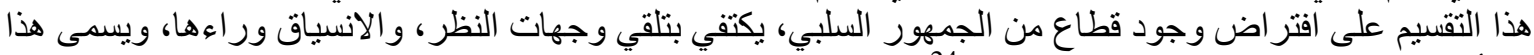

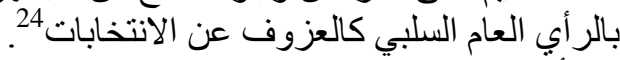
* رأي عام إيجابي: و وجود قطاع آخر يمثله عادة المثقفون، وقادة الرأي والأي والذين يملكون خلفية فكرية، ويستطيعون فهم

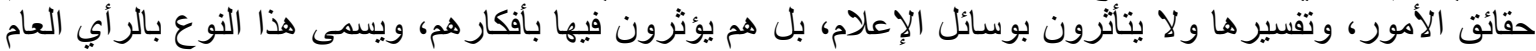

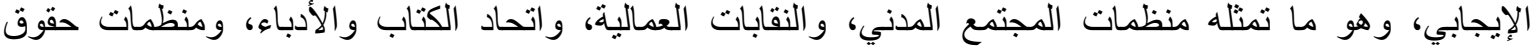
الإنسان..... الإبئ.

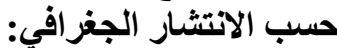

هناك من يقسم الر أبي الّعام طبقا لنطاق النتشاره الجغر افي والاجتماعي على:

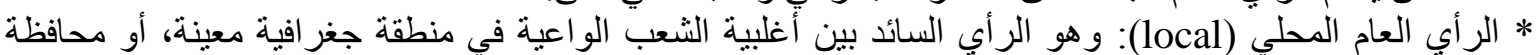

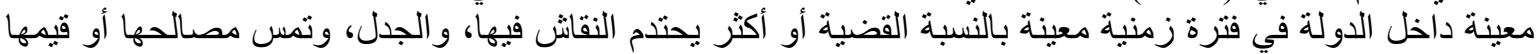

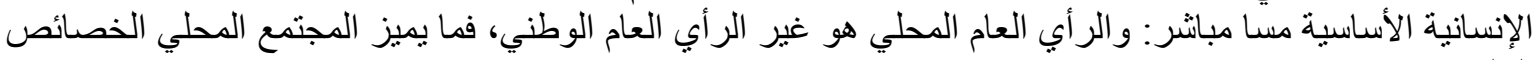
التالية: ـ الانتماء للمجتمع المحلي ـ التجانس بين الأفر اد ـ الاكتفاء الذاتي. مثنال ذلك: الصر اع الطائفي ( السنة ـ الثيعة) أو

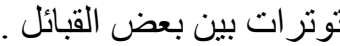
* الرأي العام الوطني: (national): يرتبط هذا النوع من الر أبي العام بالوطن أو الدولة، وتستند إلبه السلطة القائمة، ويتمبز الر أي العام الوطني بالخصائص الآتية:25:

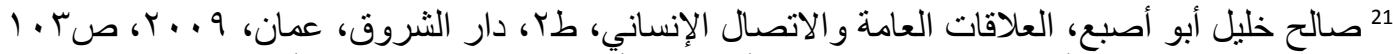

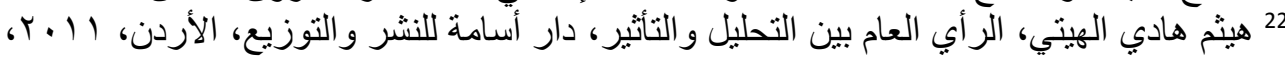

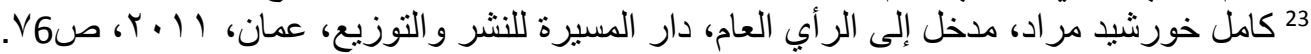

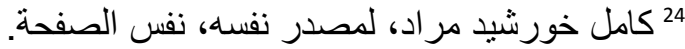




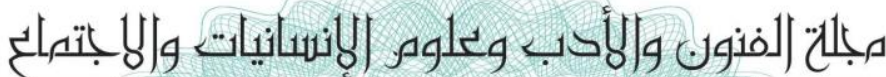

\section{العدد (39) ريران - يونيو 2019}

ـ ـ التجانس بين الأفراد لوجود خلفيات من التراث و التقاليد الراسخة فضلا عن تكاتفه حول مفاهيم معينة واضحة

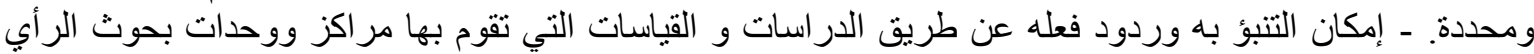

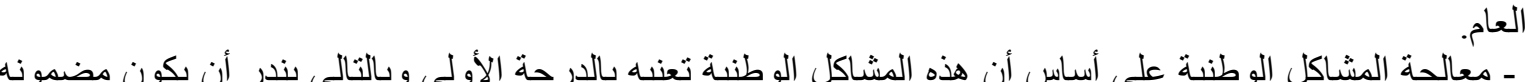

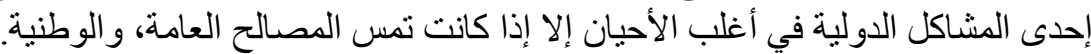

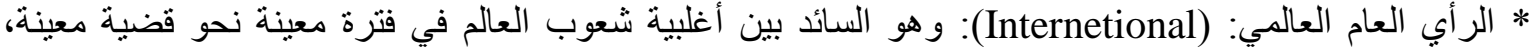

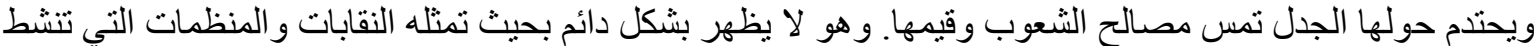

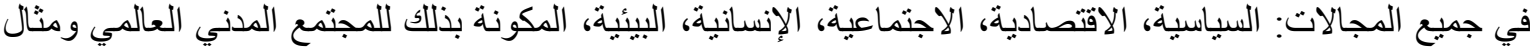

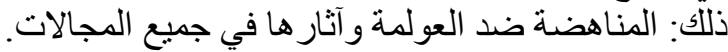

\section{حسب تأثيره وتأثره:}

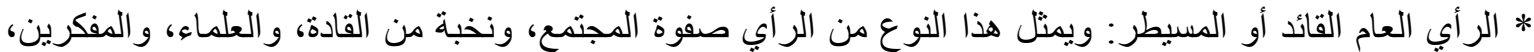

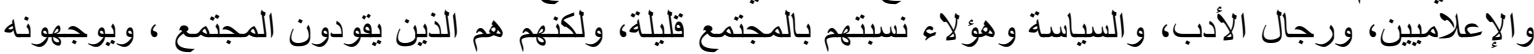

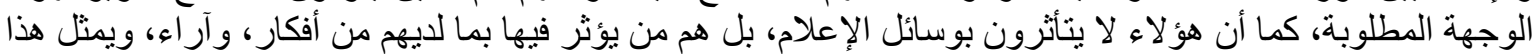

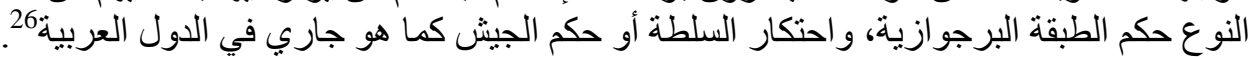

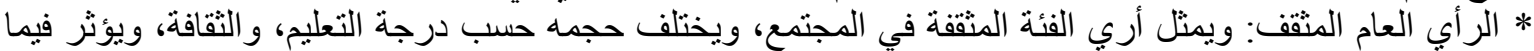

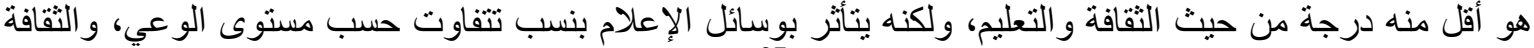

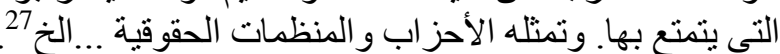

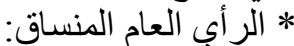

هو رأي السواد الأعظم من الناس، فهؤلاء يكونون عرضة التأثئير بسائل الإعلام، ويتقبلون ما ينشر، وما يذاع من دون تمحيص أو تدبر ويكونون عرضة الاعن لحملات الدعاية.

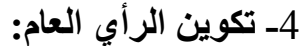

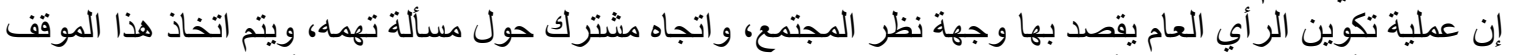

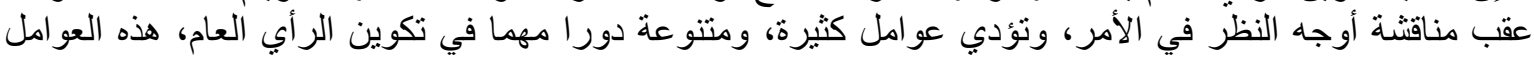

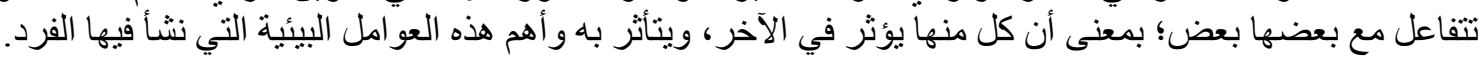

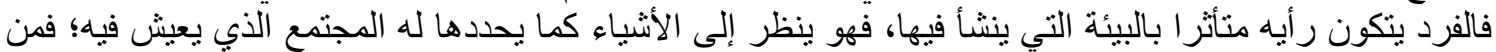

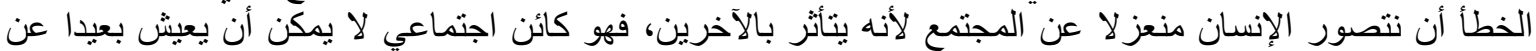

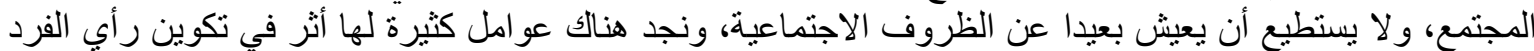

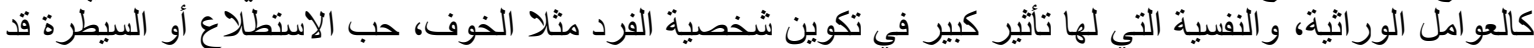

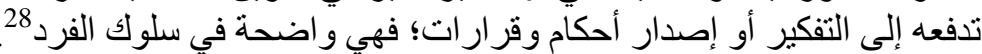

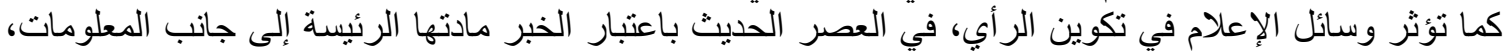

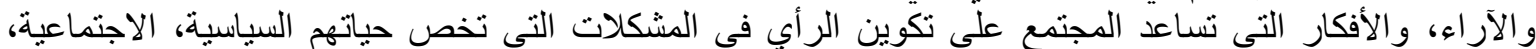

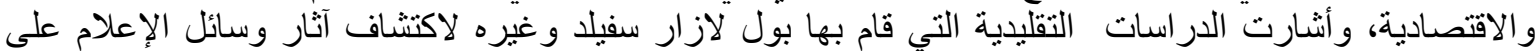

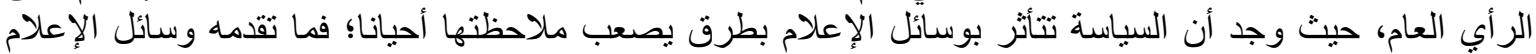

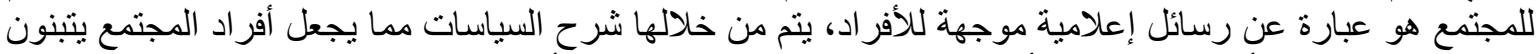

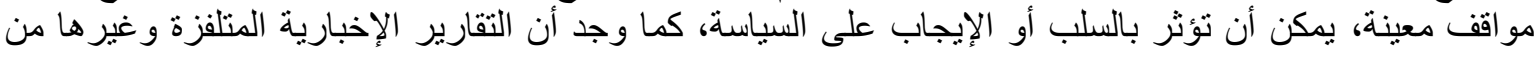

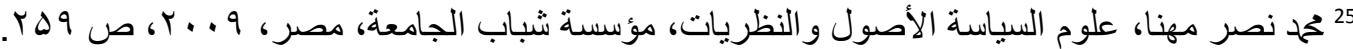

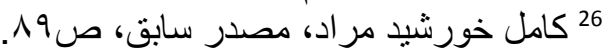
27 المصدر نفسها، نفس الصفحة. 28 هحم نصر مهنا؛ في تنظير الإعلام: الفضائيات العربية العولمة الإعلامية المعلوماتية، مؤسسة شباب المعرفة، مصر،

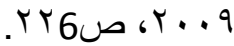




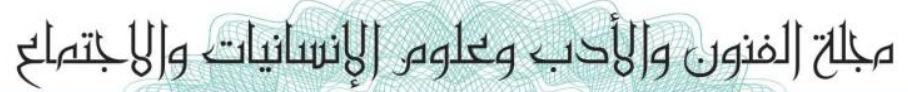

\section{العدد (39) حزيران - يونيو 2019}

النشرات الإعلامية آثار عديدة تتركها على وجهة النظر و الموقف اتجاه السياسية29.

كما تمكن الباحثون من تحديد أربعة طرق مختلفة تترك وسائل الإعلام عبر ها آثار ا على الر أي العام، وهي:

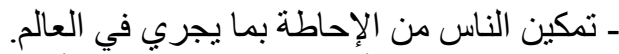

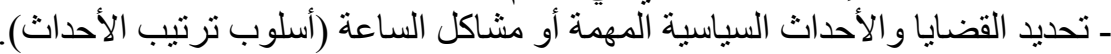

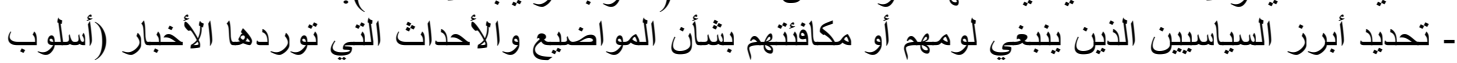
تحديد المسؤولية). ـ هناك أسلوب التأثير على الخيار ات و الميول السياسية للناس (أسلوب الاقتناع) .

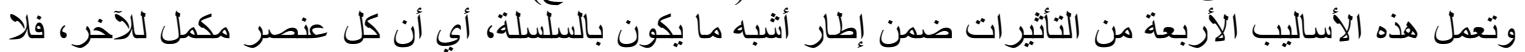

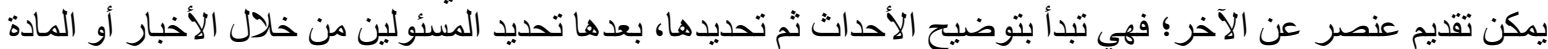

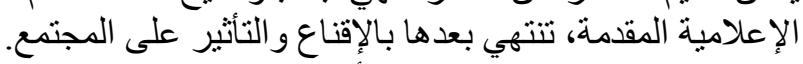

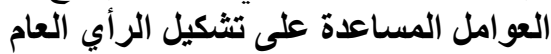

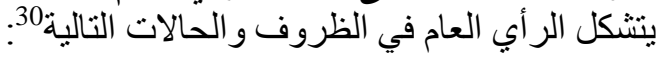

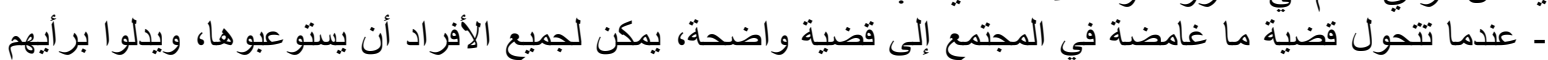

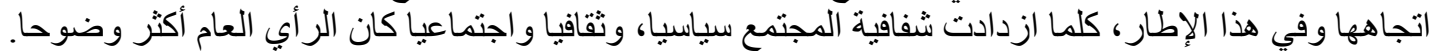

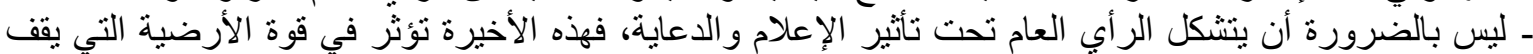

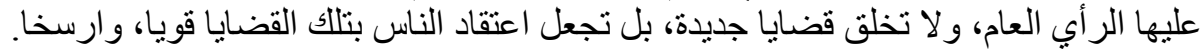
تعتبر نظرة الأفراد ودرجة تقائحم بوسائل الإعلام أرضية أساسية لظهور الرأي العام وإيجاد ثنة لإى الأفراد اتجاه

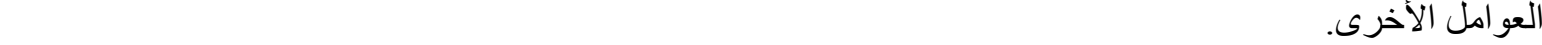
- يتشكل الر أي العام حين يشعر أفر اد المجتمع بأنهم أصحاب دور، وأري في قضايا المجتمع، وشؤونه سواء كان ذلك

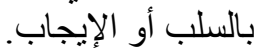
ـ يكون تشكيل الر أبي العام سريعا جدا في القضايا التي جربها المجتمع من قبل و لا تشكل شيئا جديدا بالنسبة له.

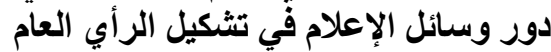

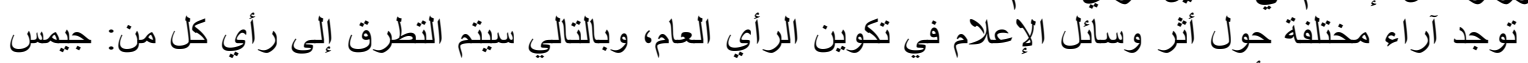
بريس، فاروق يوسف أحمد. برى جيمس أن الرأي العام يكون في حالة سلبية وهذا يرجع إلى إلى العوامل الثقافية، والتعليمية للأفراد أو الأسباب

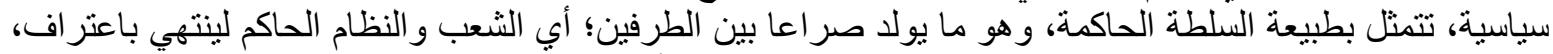

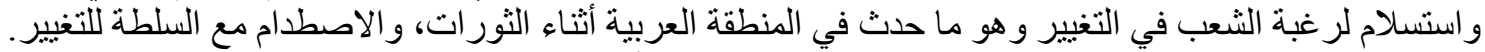

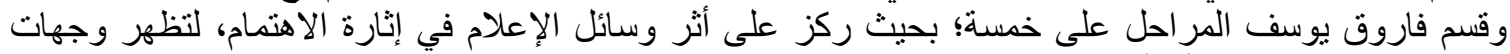

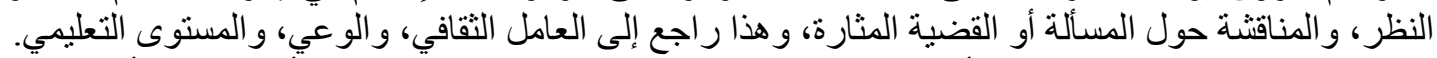

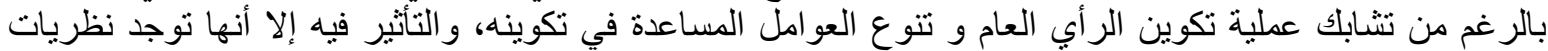

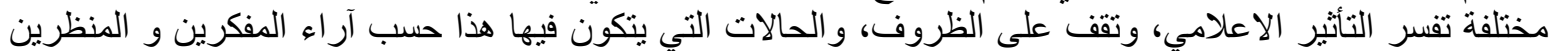

29 منذر صالح جاسم الزبيدي، دور وسائل الإعلام في صنع القرار السياسي، دار الحامد للنشر والتوزيع، عمان، با ـ ب، ص .154..-1.r

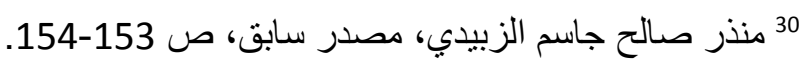

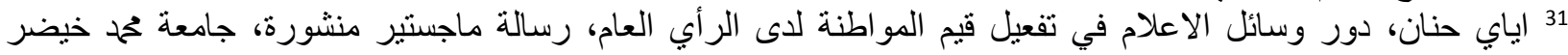

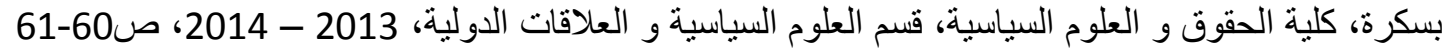




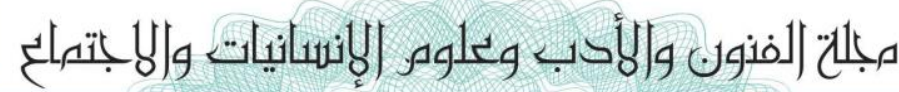

\section{العدد (39) حزيران - يونيو 2019}

يتناول الباحث في هذا المبحث اتجاهات الجمهور العام نحو (دور وسائل الاعلام في تشكيل الرأي العام)، و الجداول التالية توضح ذلك:

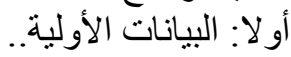

\begin{tabular}{|c|c|c|}
\hline النسبة المئوية & التكرار & الجنس \\
\hline$\% 78$ & 39 & ذكر \\
\hline$\% 22$ & 11 & أنتى \\
\hline$\% 100$ & 50 & المجموع \\
\hline
\end{tabular}

يتضح من الجدول السابق أن أغلب أفر اد عينة الدر اسة من الذكور بنسبة ( 78\% )، في حين بلغت نسبة الإناث ( \%22 ) من مجتمع عينة الدراسة.

الجدول رقم (2) يبين الحالة الاجتماعية للمبحوثين

\begin{tabular}{|c|c|c|}
\hline النسبة المئوية & التكرار & البيان \\
\hline$\% 72$ & 36 & متزوج \\
\hline$\% 28$ & 14 & أعزب \\
\hline$\% 100$ & 50 & المجموع \\
\hline
\end{tabular}

يتبين من الجدول رقم (2) أن أغلب المبحوثين هم من المنزوجين بنسبة ( 72\% )، بينما كانت نسبة العزاب من أفراد

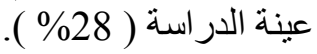

جدول رقم (3) يبين توزيع أفراد عينة الدراسة حسب الأعمار

\begin{tabular}{|c|c|c|}
\hline النسبة المئوية & التكرار & العمر \\
\hline$\% 12$ & 6 & 18 - أقل من 22 \\
\hline$\% 18$ & 9 & 22 - أقل من 26 \\
\hline$\% 28$ & 14 & 26 - أقلّ من 30 \\
\hline$\% 42$ & 21 & 30 فما فوق \\
\hline$\% 100$ & 50 & المجموع \\
\hline
\end{tabular}




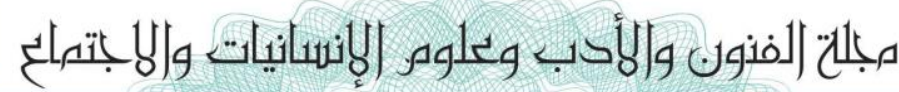

\section{العدد (39) حزيران - يونيو 2019}

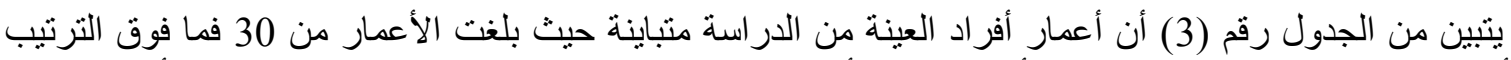

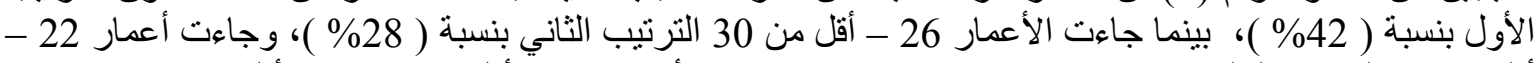

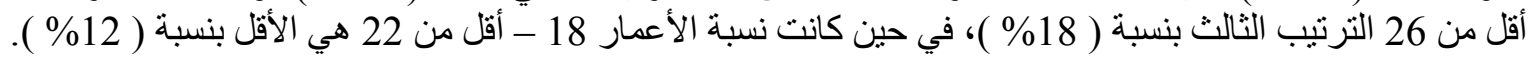

\begin{tabular}{|c|c|c|}
\hline النسبة المئوية & التكرار & المستوى \\
\hline$\% 4$ & 2 & يقرأ و يكتب \\
\hline$\% 8$ & 4 & ابتدائية \\
\hline$\% 24$ & 12 & ثانوي \\
\hline$\% 58$ & 29 & بكالوريوس \\
\hline$\% 6$ & 3 & شهادة عليا \\
\hline$\% 100$ & 50 & المجموع \\
\hline
\end{tabular}

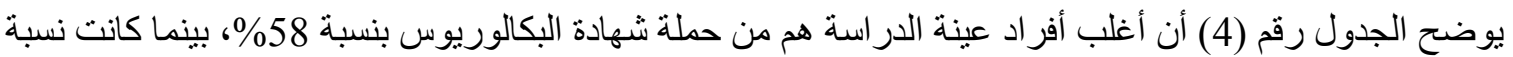

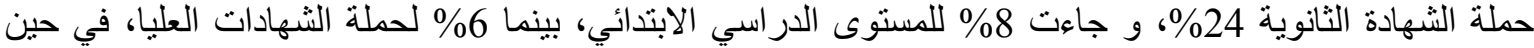
كانت نسبة من يقر أو يكتب فقط 4\% و من المبحوثين.

\begin{tabular}{|c|c|c|}
\hline النسبة المئوية & التكرار & المهنة \\
\hline$\% 24$ & 12 & طالب \\
\hline$\% 38$ & 19 & موظف \\
\hline$\% 12$ & 6 & كاسب \\
\hline$\% 26$ & 13 & متقاعد \\
\hline$\% 100$ & 50 & المجموع \\
\hline
\end{tabular}

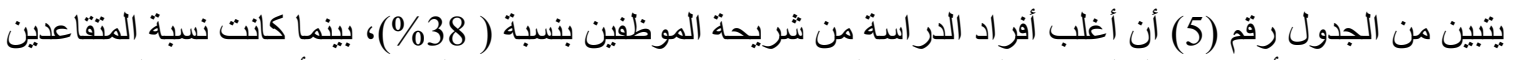

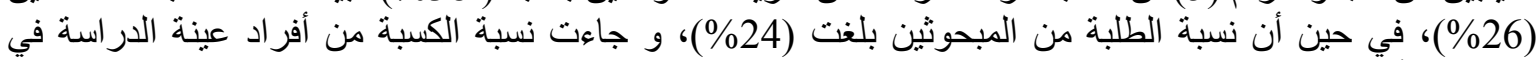
الترتيب الأخير بنسبة (12\%). 


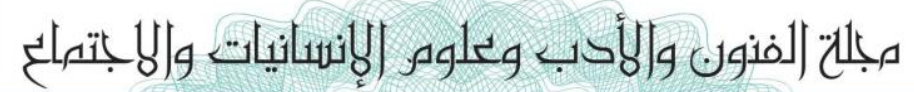

\section{العدد (39) رزيران - يونيو 2019}

\begin{tabular}{|c|c|c|}
\hline النسبة المئوية & التكرار & الوقت \\
\hline$\% 22$ & 11 & أقل من ساعة \\
\hline$\% 20$ & 10 & 2-1 ساعة \\
\hline$\% 44$ & 22 & 2 - 3 ساعة \\
\hline$\% 14$ & 7 & أكثر من 3 ساعات \\
\hline$\% 100$ & 50 & المجموع \\
\hline
\end{tabular}

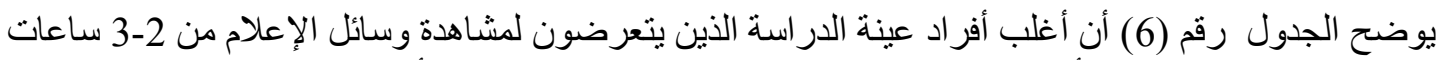

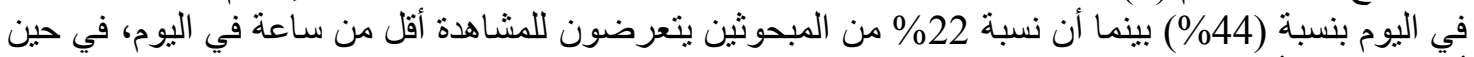

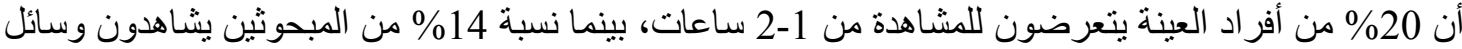
الإعلام أكثر من 3 ساعات في اليوم.

جدول رقم (7) : يبين أكثر وسائل الإعلام اعتمادا للحصول على المعلومات

\begin{tabular}{|c|c|c|}
\hline النسبة المئوية & التكرار & الوسيلة \\
\hline$\% 32$ & 16 & التلفزيون \\
\hline$\% 18$ & 9 & الإذاعة \\
\hline$\% 8$ & 4 & الصحف \\
\hline$\% 42$ & 21 & مواقع الانترنت \\
\hline$\% 100$ & 50 & المجموع \\
\hline
\end{tabular}

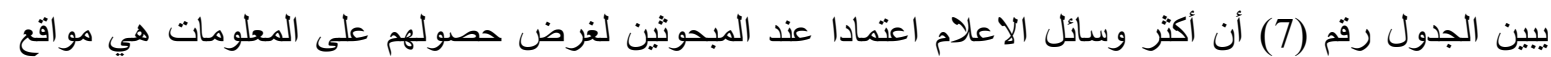

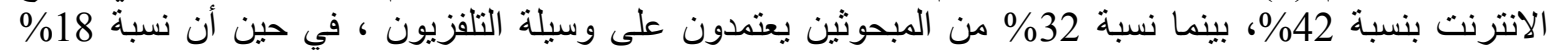

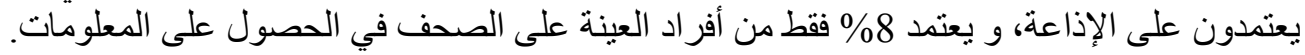

جدول رقم (8): يبين مدى درجة الاعتماد على وسائل الاعلام في تثكيل الرأي الآراء

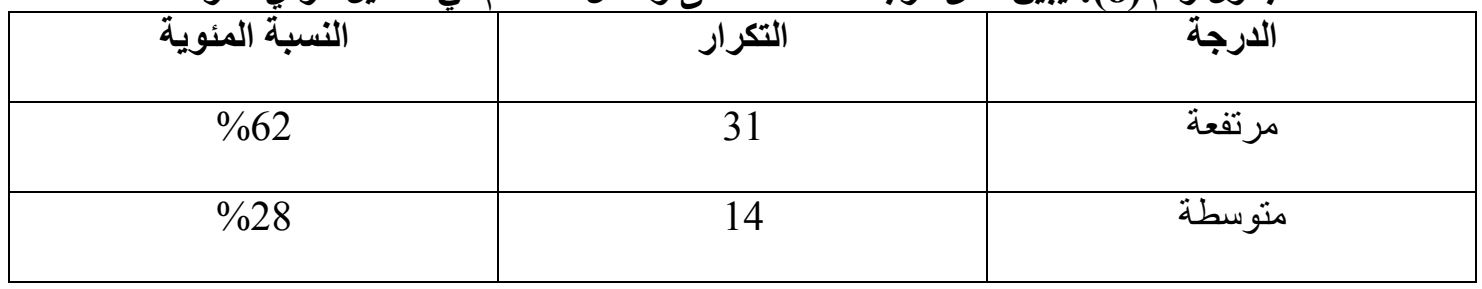




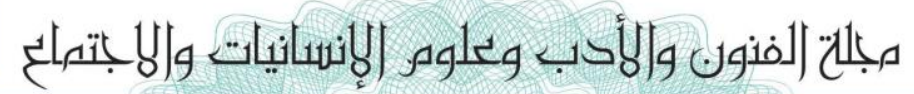

\section{العدد (39) رزيران - يونيو 2019}

\begin{tabular}{|c|c|c|}
\hline$\% 10$ & 5 & \\
\hline$\% 100$ & 50 & المجفونة \\
\hline
\end{tabular}

بتضح من الجدول رقم (82) أن أغلب أفراد عينة الدر اسة بعتمدون على وسائل الإعلام بدرجة مرتفعة من أجل تشكيل

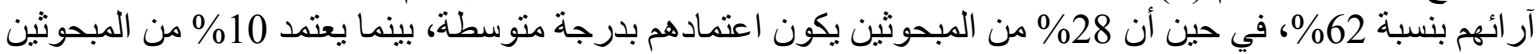
بدرجة منخفضة على وسائل الإعلام في تشكيل آر ائهم.

جدول رقم (9) : يبين مدى مساهمة المعلومات التي تقدمها وسائل الاعلام في تثكيل الآراء حول مختلف القضايا

\begin{tabular}{|c|c|c|}
\hline النسبة المئوية & التكرار & البيان \\
\hline$\% 58$ & 29 & نعم \\
\hline$\% 12$ & 6 & y \\
\hline$\% 30$ & 15 & إلى حد ما \\
\hline$\% 100$ & 50 & المجموع \\
\hline
\end{tabular}

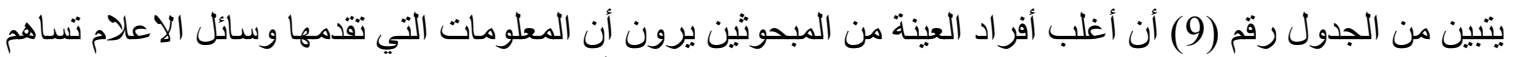

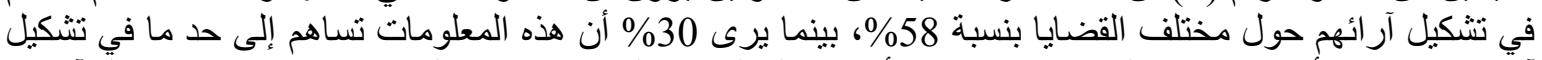
آرائهم، في حين أن 12\% من المبحوثين لا يرون أن هذه المعلومات التي تقدمها وسائل الإعلام تساهم في تشكيلّ آر ائهم

حول مختلف القضايا.

جدول رقم ( 10 ) : يبين مدى الاعتماد على وسائل الاعلام في بناء الثقافة

\begin{tabular}{|c|c|c|}
\hline النسبة المئوية & التكرار & البيان \\
\hline$\% 56$ & 28 & نعم \\
\hline$\% 24$ & 12 & كلا \\
\hline$\% 20$ & 10 & الى حد ما \\
\hline$\% 100$ & 50 & المجموع \\
\hline
\end{tabular}

تبين من الجدول رقم(10)أن اغلب أفراد العينة من المبحوثين يعتمدون على وسائل الإعلام في بناء ثقافتهر

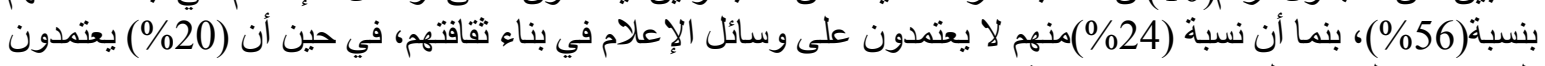
إلى حد ما على وسائل الإعلام في بناء ثقافتهم. 


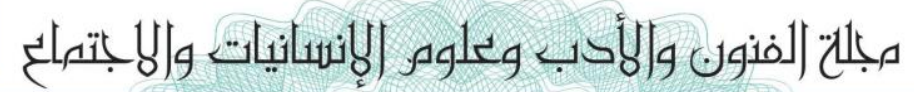

\section{العدد (39) حزيران - يونيو 2019}

\begin{tabular}{|c|c|c|}
\hline النسبة المئوية & التكرار & البيان \\
\hline$\% 46$ & 23 & نعم \\
\hline$\% 24$ & 12 & إلى حد ما \\
\hline$\% 30$ & 15 & $\gamma$ \\
\hline$\% 100$ & 50 & المجموع \\
\hline
\end{tabular}

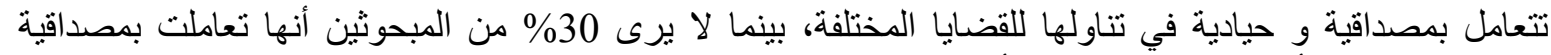
وحيادية، في حين أن 24\% يذهبون إلى أن وسائل الاعلام تعاملت بمصداقية و حيادية إلى حد ما في تتاولها للقضايا المختلفة

جدول رقم (12): يبين مدى فاعلية تأثير وسائل الاعلام على زيادة الوعي و المعرفة بالقضايا

\begin{tabular}{|c|c|c|}
\hline النسبة المئوية & التكرار & البيان \\
\hline$\% 52$ & 26 & نعم \\
\hline$\% 30$ & 15 & إلى حذ ما \\
\hline$\% 18$ & 9 & y \\
\hline$\% 100$ & 50 & المجموع \\
\hline
\end{tabular}

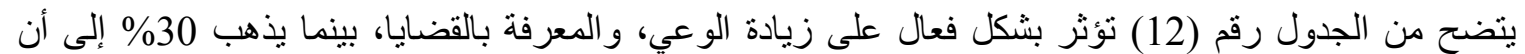

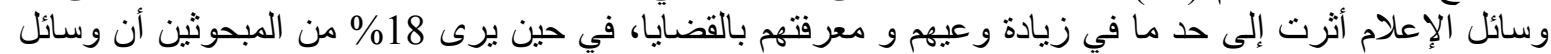

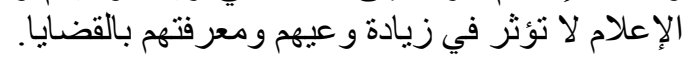

جدول رقم (13): يبين مدى تلبية وسائل الإعلام لجميع الاهتمامات وتقديم المعلومات

\begin{tabular}{|c|c|c|}
\hline النسبة المئوية & التكرار & البيان \\
\hline$\% 36$ & 18 & نعم \\
\hline$\% 42$ & 21 & إلى حد ما \\
\hline$\% 22$ & 11 & $\gamma$ \\
\hline$\% 100$ & 50 & المجموع \\
\hline
\end{tabular}




\section{العدد (39) حزيران - يونيو 2019}

يتضح من الجدول رقم (13) أن أغلب أفراد عينة الدر اسة يذهبون إلى حد ما أن وسائل الإعلام تلبي جميع اهتماماتهم

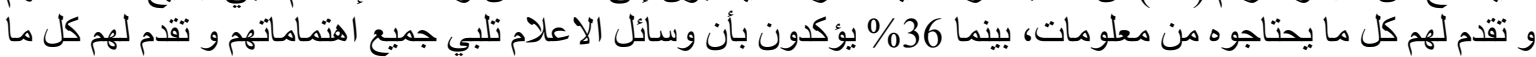
يحتاجوه من معلومات، في حين أن 22\% لا يرون أن وسائل الاعلام تلبي جميع اهتماماتهم و تقدم لهم كل ما يحتاجوه من معلومات.

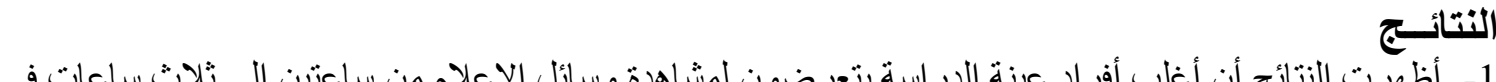
1- أظهرت النتائج أن أغلب أفر اد عينة الدر اسة يتعرضون لمشاهدة وسائل الإعلام من ساعتين إلى ثلاث ساعات في

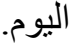
Y. تبين أن أكثر وسائل الإعلام اعتماد عند المبحوثين لغرض حصولهم على المعلومات هي مواقع الانترنت.

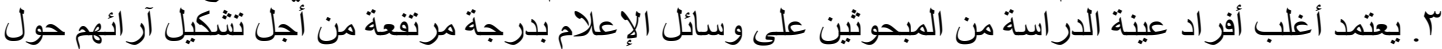
مختلف القضايا التي تقدمها هذه الوسائل. 4. أن المعلومات التي تقدمها وسائل الإعلام تساهم في تشكيل آر اء المبحوثين حول مختلف القضايا بشكل كبير. 5. أظهرت النتائج أن أغلب أفراد عينة الدر اسة من المبحوثين بعتمدون على وسائل الإعلام في بناء ثقافتهم.

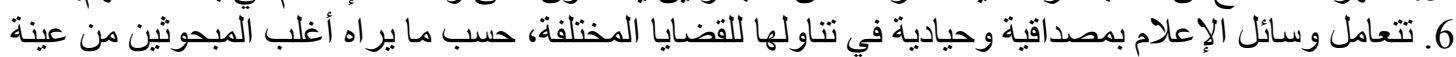
الدر اسة. V. ذهب أغلب أفر اد عينة الدر اسـة إلى أن وسائل الإعلام تؤثر بشكل فعال على زيادة الوعي، و المعرفة بالقضايا التي تطرحها وتقدمها. ^. تبين أن أغلب أفر اد عينة الدر اسة يرون إلى حد ما أن وسائل الإعلام تلبي جميع اهتماماتهم وتقدم لهم كل ما يحتاجوه من معلو مات.

الثّوصبـات

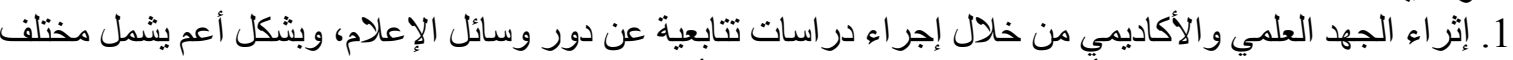

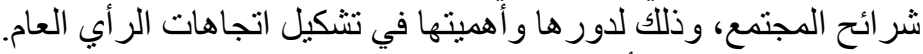

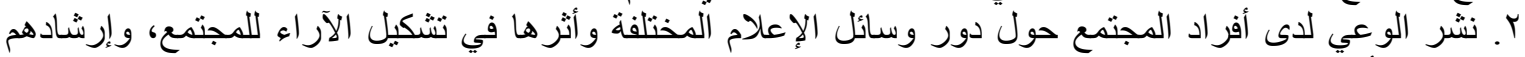

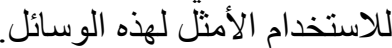
3. أن تطرح وسائل الإعلام القضايا التي تهم المجتمع، وتتعلق بالحريات وحرية التعبير و الرأي العام دون المساس بحرية الآخرين.

4. ضرورة أن تعمل وسائل الإعلام على زيادة الوعي و المعرفة بالقضايا المختلفة التي تساهم في تغيير سلوك الأفر اد. 5. الاهتمام الكبير بمضامين الموضو عات التي تقدمهاً وسائل الإعلام لتلبية حاجات المجتمع الفكرية و الاجتماعية.

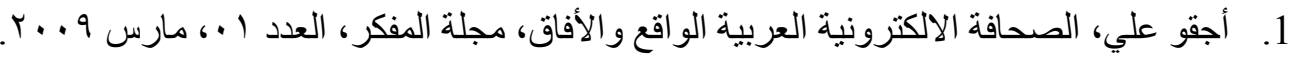

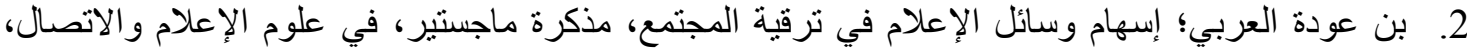

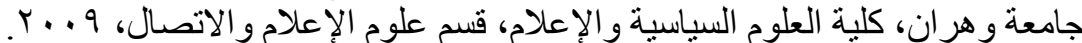

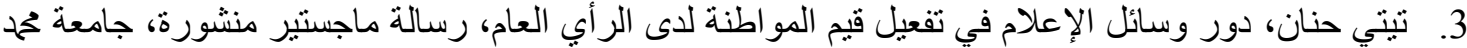

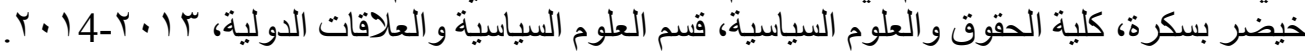

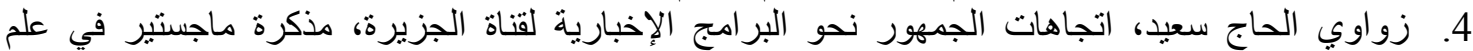

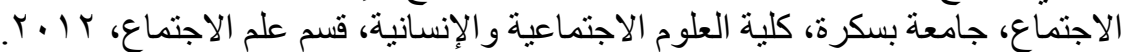

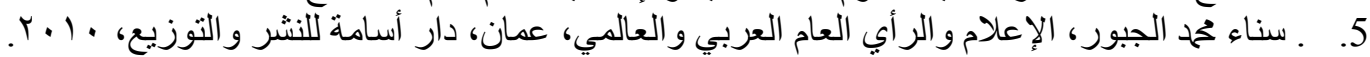

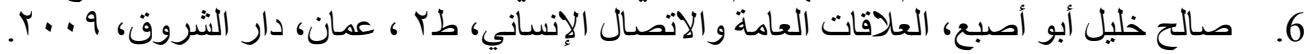

7.

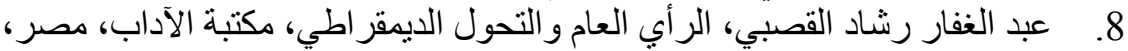




\section{العدد (39) حزيران - يونيو 2019}

9. عبد الوهاب الكيالي وآخرون، موسوعة السياسة، الجزء الثاني، المؤسسة العربية للاراسات و النشر، لبنان، .1991

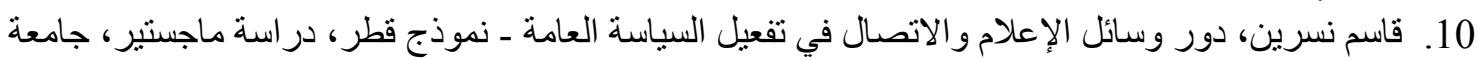

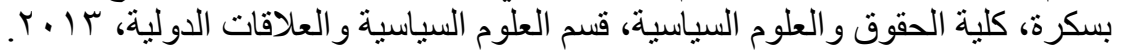

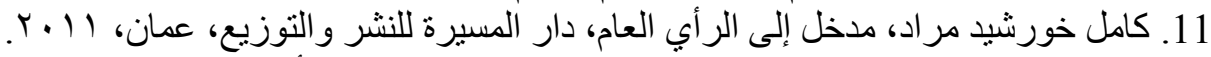

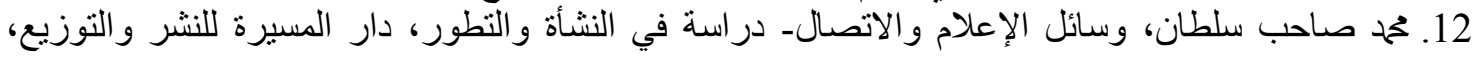
$r+11$

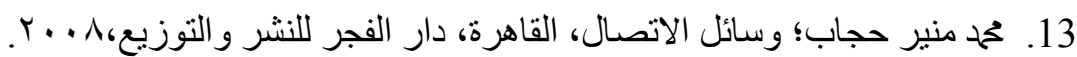

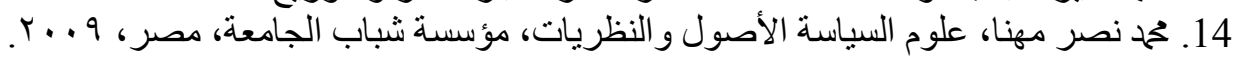

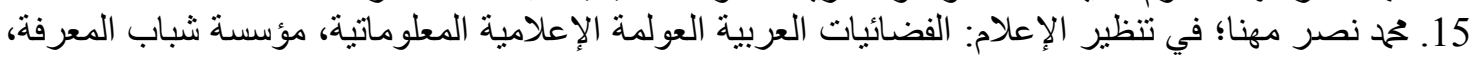

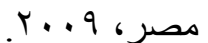

16. مختار بمينه؛ آثز الأحداث السياسية المشاهدة على التنشئة السياسية للطفل على التلفزيون، مذكرة ماجستير،

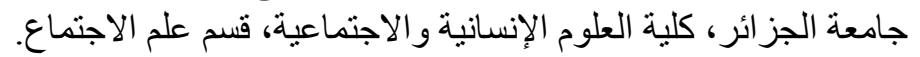

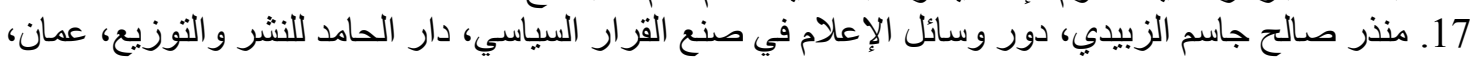
r. 1 r 18. هيثم هادي الهيتي، الر أي العام بين التحليل والتأثير، دار أسامة للنشر والتوزيع، الأردن، 11 بـ. 


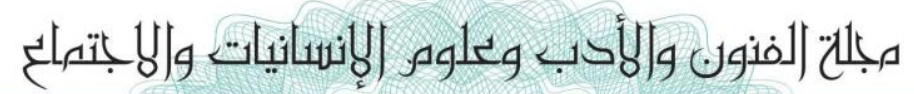

\section{العدد (39) حزيران - يونيو 2019}

يجري الباحث در اسة ميدانية حول (دور وسائل الإعلام في تشكيل الر أي العام) يرجى التفضل بالإجابة على الأسئلة

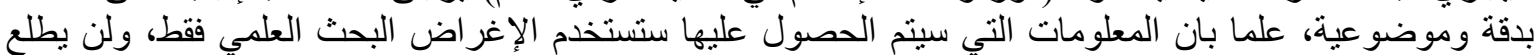

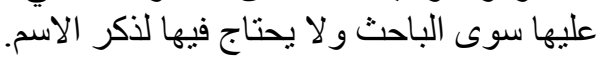

(بنود الاستبانة)

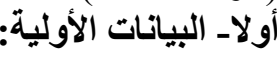

$$
\text { 1- الجنس: ذكر البياتس الأية: }
$$

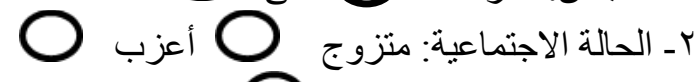

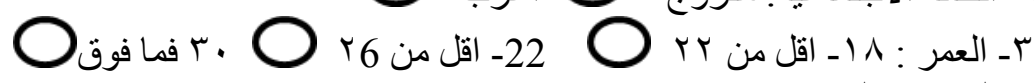

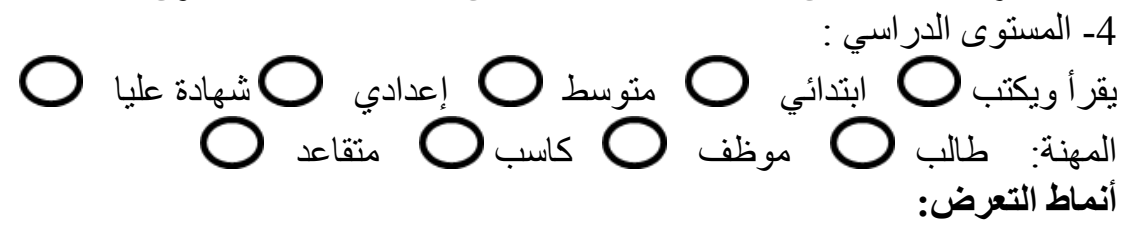

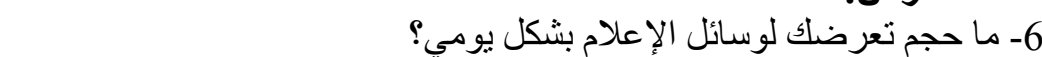

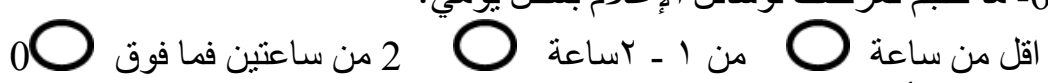

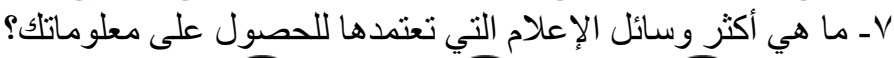

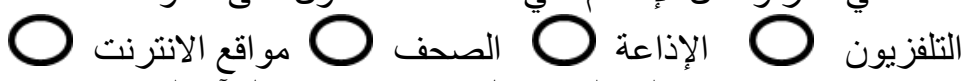

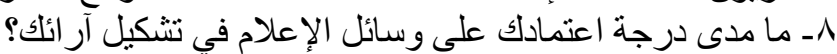

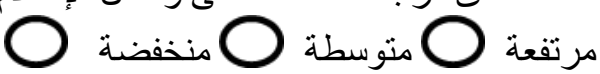
9- هل تساهم المعلومات التي تقدمها وسائل الإعلام في تشكيل آر ائك حول مختلف القضايا؟

نعم • ا ـ هل تعتمد على وسائل الإعلام في بناء ثقافتلك ؟

نعم 11- هل ترى أن وسائل الإعلام تتناول القضايا المختلفة بصدق وحيادية؟

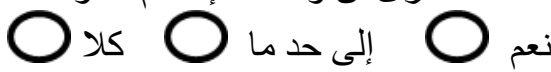

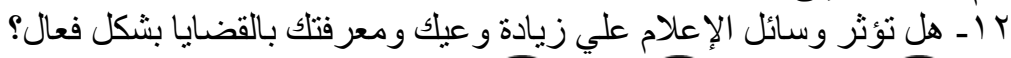

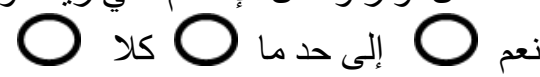

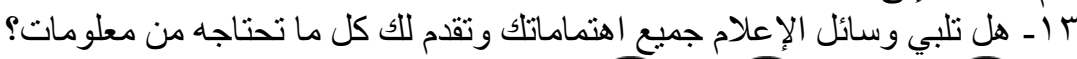
نعم 